\title{
RECENT STUDIES OF HISTORICAL EARTHQUAKE-INDUCED LANDSLIDING, GROUND DAMAGE, AND MM INTENSITY IN NEW ZEALAND
}

\author{
G. T. Hancox ${ }^{1}$, N. D. Perrin ${ }^{1}$ and G. D. Dellow ${ }^{1}$
}

\begin{abstract}
A study of landsliding caused by 22 historical earthquakes in New Zealand was completed at the end of 1997. The main aims of that study were to: (a) study the nature and extent of landsliding and other ground damage (sand boils, subsidence and lateral spreading due to soil liquefaction) caused by historical earthquakes; (b) determine relationships between landslide distribution and earthquake magnitude, epicentre, isoseismals, faulting, geology and topography; and (c) establish improved environmental response criteria and ground classes for assigning MM intensities and seismic hazard assessments in New Zealand.
\end{abstract}

Relationships developed from the study indicate that the minimum magnitude for earthquake-induced landsliding (EIL) in N.Z. is about M 5, with significant landsliding occurring at M 6 or greater. The minimum MM intensity for landsliding is MM6, while the most common intensities for significant landsliding are MM7-8. The intensity threshold for soil liquefaction in New Zealand was found to be MM7 for sand boils, and MM8 for lateral spreading, although such effects may also occur at one intensity level lower in highly susceptible materials. The minimum magnitude for liquefaction phenomena in N.Z. is about M 6, compared to M 5 overseas where highly susceptible soils are probably more widespread.

\begin{abstract}
Revised environmental response criteria (landsliding, subsidence, liquefaction-induced sand boils and lateral spreading) have also been established for the New Zealand MM Intensity Scale, and provisional landslide susceptibility Ground Classes developed for assigning MM intensities in areas where there are few buildings. Other new data presented include recent earthquake studies (e.g., Murchison 1929), a preliminary landslide size/frequency distribution for earthquakes over the last 150 years, and a preliminary EIL Opportunity and hazard model for New Zealand. Implications for earthquake-induced landsliding for seismic hazard assessments in New Zealand are briefly discussed. Suggestions are also made for future EIL research, including further studies of historical earthquakes, and large prehistoric landslides in the central Southern Alps, northwest Nelson, and Fiordland, to help determine past and future earthquake activity and hazard from active faults in those regions.
\end{abstract}

\section{INTRODUCTION}

Landslides have occurred during many historical earthquakes in New Zealand. Since 1840, at least 22 earthquakes have resulted in substantial or widespread and damaging landsliding (Figure 1 and Table 1). The substantial damage caused by earthquake-induced landsliding (EIL) has been second only to building damage caused by strong shaking. Some buildings have been destroyed, and many roads have been damaged and closed by landslides and rock falls. In only two major earthquakes seventeen people have been killed (two by falls in coal mines). Sixteen deaths resulted from landslides triggered by the 1929 Murchison earthquake alone.
The landsliding and ground damage caused by these earthquakes was recently the subject of a comprehensive study (EQC Research Project 95/196), which was jointly funded by the Earthquake Commission (EQC) and the Foundation for Research Science and Technology (FRST).The complete results of the study are presented in an Institute of Geological and Nuclear Sciences Limited report (Hancox et al., 1997). This paper presents a summary of that report (referred to here as the 1997 study), and also other related research since it was completed.

\subsection{Background}

${ }^{1}$ Engineering Geologists, Institute of Geological \& Nuclear Sciences Ltd., Gracefield, Lower Hutt. 
Earthquake shaking causes landslides in several ways, including: (a) horizontal accelerations temporarily increase (gravitational) shear stresses within a slope; (b) the strength of slope materials is decreased due to a reduction in intergranular bonding; and (c) cyclic loading causes increased pore pressures in slope materials, which results in strength loss and possibly soil liquefaction in sands and silts.
It is generally accepted that the severity of landsliding caused by earthquakes depends on a combination of factors, but especially earthquake strength, depth, and location, together with local site conditions (topography, soil and rock types). Many of the large catastrophic landslides in New Zealand and overseas have been triggered by earthquakes.

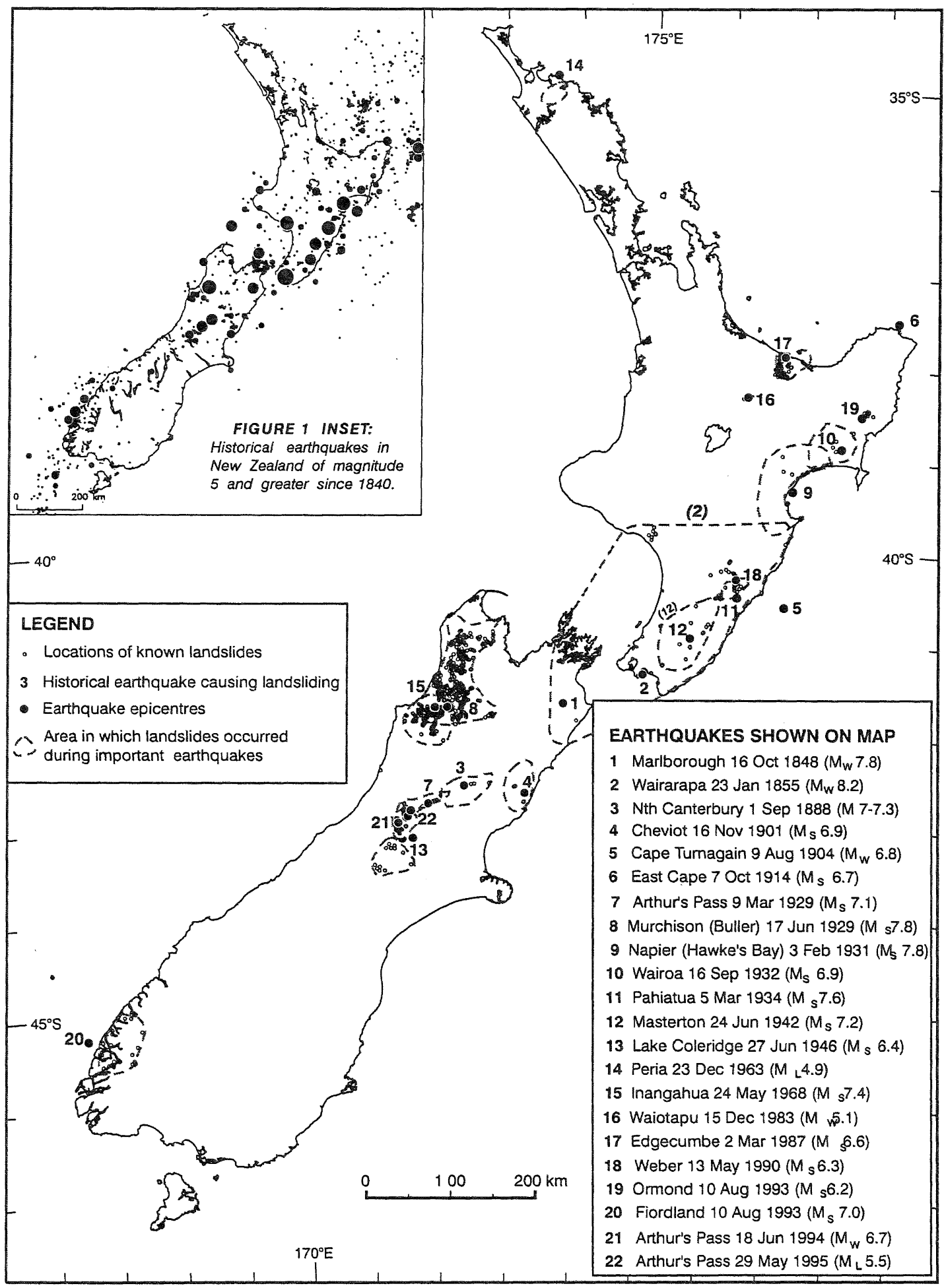

Figure 1. Map showing the epicentres of historical earthquakes that have caused substantial landsliding in New Zealand. The approximate locations of the main landslides are indicated by small dots, and the dashed lines show the extent of the landslide-affected areas for several important earthquakes (numbers in brackets). 


\subsubsection{Overseas studies}

In the last 20 years, overseas studies have provided considerable information on the types of landslides caused by earthquakes, and the different shaking (MM) levels at which they occur (for example Keefer, 1984 a, 1984 b; Keefer and Wilson, 1989; and Jibson, 1996). Earthquake-induced landslides have also been used in a number of palaeoseismic studies overseas (e.g., Jibson and Keefer, 1989; Jibson, 1996). Keefer (1984 a) studied 40 historical earthquakes worldwide and several hundred earthquakes from the United States to determine the characteristics, geologic environments, and hazards of landslides caused by seismic events. The Keefer (1984 a) study: (a) identified the main types of landslides caused by earthquakes (rock falls, disrupted soil slides, and rock slides most abundant); (b) determined relationships between earthquake magnitude and the area affected by landslides, and the maximum distance of earthquake-induced landslides, spreads and flows from the epicentre and fault rupture zone; and (c) established threshold magnitudes and minimum shaking intensities that trigger landslides in susceptible materials.

For earthquake-induced landsliding to occur, Keefer (1984 a) determined a minimum shaking intensity 'of MM4, with a minimum magnitude of about M4.0. The data from which the minimum threshold levels for EIL, and relationships between magnitude and shaking intensity and the area affected by landsliding and epicentral distance were dominated by United States earthquakes, and are of uncertain relevance in New Zealand. Some previous hazard studies in New Zealand (e.g., McCahon, et al., 1993; Hancox et al., 1994) suggested that the threshold magnitude and shaking intensity levels for earthquake-induced landsliding in this country were likely to be somewhat higher than those determined for overseas earthquakes by Keefer (1984 a).

\subsubsection{New Zealand studies}

Landsliding and ground damage caused by historical earthquakes in New Zealand (Table 1) is variably documented and described in detail for only a few events. Of the earlier earthquakes, brief written descriptions are given of landslides caused by the 1929 Arthur's Pass (Speight, 1933) and the 1931 Hawke's Bay (Baird, 1931) earthquakes. More detailed accounts are given of landsliding triggered by the 1929 Murchison (Buller) earthquake (Henderson, 1937; Pearce and O'Loughlin, 1985), although the complete landslide distribution was not mapped. Better descriptions are given of landslides caused by more recent larger earthquakes such as: Inangahua 1968 (Adams et al., 1968); Edgecumbe 1987 (Franks et al., 1989); Weber 1990 (Perrin 1990); Fiordland 1993 (Van Dissen et al. 1994); Ormond 1993 (Read and Sritharan, 1993); and Arthur's Pass 1994 (Paterson and Bourne-Webb, 1994).

Earthquake-induced landslides have also been used in a few palaeoseismic studies in New Zealand (e.g., Adams, 1980,
1981; Crozier et al., 1995). Such studies rely on convincing evidence of the seismic origin of the landslides by a single earthquake, which is difficult to obtain for prehistoric earthquakes. Extensive radiocarbon and dendrochronology (tree-ring) dating is usually required to support a probable coeval (about the same age, based on vegetation and geomorphology) and earthquake origin of a group of old landslides.

Landslide damage provides an indication of the area affected by the earthquake, from which an indication of the earthquake epicentre and magnitude can be determined. Using data from the 1929 Murchison earthquake, Adams (1981) concluded that the area containing landslide-dammed lakes formed during an earthquake is an indication of the area shaken to intensity MM10, and used this approach to develop an expression to define the relationship between earthquake magnitude and the area affected by landslides, as follows:

$$
M_{s}=0.5 \log _{10}(A x)+5.9
$$

(where $\mathrm{M}_{\mathrm{s}}$ is surface wave magnitude, and $\mathrm{Ax}$ is the area $\left(\mathrm{km}^{2}\right)$ affected by MM10 shaking).

However, more recent studies (Dowrick, 1994; 1996) suggest that this relationship might not apply as areas formerly designated as MM10 have now been downgraded to MM9 or MM8.

\subsubsection{Landslides and MM Intensity in New Zealand}

Landslides triggered by historical earthquakes in New Zealand have often been used in assigning Modified Mercalli (MM) intensities for these events. However, landslide effects are poorly defined in previously published New Zealand versions of the MM scale (Eiby, 1966; Study Group of the NZNSEE, 1992). Prior to the 1997 EIL study, a few papers had been published on landslides during some New Zealand earthquakes (e.g., Speight, 1933; Henderson, 1937; Adams, et al., 1968; Pearce and O'Loughlin, 1995; Franks, et al., 1989; Paterson and Bourne-Webb, 1994). There were, however, no comprehensive overview studies of earthquakeinduced landsliding in New Zealand, and little published data correlating landsliding with $\mathrm{MM}$ intensities and other seismicity parameters.

A Study Group of the New Zealand National Society for Earthquake Engineering carried out revision of the Modified Mercalli Seismic Intensity scale for use in New Zealand in 1991 (Study Group of the NZNSEE, 1992). The Study Group made a number of changes to the NZ 1965 version (Eiby, 1966). Since the revision was primarily aimed at making the MM scale appropriate for modern (earthquake resistant) construction, most of the changes related to building damage, although some were intended to better define earthquake shaking effects on the environment such as landslides and ground damage resulting from liquefaction phenomena (mainly sand boils and lateral spreads). 
Table 1. Historical earthquakes causing substantial landsliding in New Zealand

\begin{tabular}{|c|c|c|c|c|c|}
\hline NAME (\& Number) & DATE & MAGNITUDE & $\underset{k m^{(2)}}{\text { DEPTH }}$ & EFFECTS $^{(4)}$ & KEY REFERENCES \\
\hline $\begin{array}{l}\text { (1) Marlborough } \\
\text { (formerly M 7.1) }\end{array}$ & 16 Oct 1848 & $M_{w} 7.5$ & 10 & $\begin{array}{l}\text { MM9 in Wairau and Awatere valleys; } \\
\text { surface faulting in Awatere valley. } \\
\text { Many slides in epicentral area. }\end{array}$ & [17], [23], GNS Files ${ }^{3}$ \\
\hline $\begin{array}{l}\text { (2) Wairarapa } \\
\text { (formerly M 8.2) }\end{array}$ & 23 Jan 1855 & $M_{w} 8.2$ & 20 & $\begin{array}{l}\text { MM9 in Wellington; widespread } \\
\text { landsliding in Wellington region. }\end{array}$ & [17], [19], [22] \\
\hline (3) Nth Canterbury & 1 Sep 1888 & $M_{w} 7-7.3$ & 10 & Surface faulting at Glynn Wye & [9], [17] \\
\hline (4) Cheviot & 16 Nov 1901 & $\begin{array}{l}M_{s} 6.9 \\
M_{w} 6.8\end{array}$ & 10 & Landslides at MM8-9; roads blocked & {$[17]$} \\
\hline (5) Cape Turnagain & 9 Aug 1904 & $\begin{array}{l}M_{s} 6.8 \\
M_{w} 6.7\end{array}$ & LC & $\begin{array}{l}\text { Widespread damage and landslides in } \\
\text { Nth Wairarapa. }\end{array}$ & {$[11],[17]$} \\
\hline (6) East Cape & $\begin{array}{l}7 \text { Oct } 1914 \\
28 \text { Oct } 1914 \\
\end{array}$ & $\begin{array}{l}M_{s} 6.7 \\
M_{s} 6.4\end{array}$ & S & $\begin{array}{l}\text { Significant landsliding; } 1 \text { death, not } \\
\text { related to landsliding (not Isr). }\end{array}$ & {$[11]$} \\
\hline (7) Arthur's Pass & 9 Mar 1929 & $\begin{array}{l}M_{s} 7.1 \\
M_{w} 7.0\end{array}$ & $<15$ & $\begin{array}{l}\text { Widespread landslides in mountainous } \\
\text { country. }\end{array}$ & {$[17],[50],[59]$} \\
\hline $\begin{array}{l}\text { (8) Murchison } \\
\text { (Buller) }\end{array}$ & 17 Jun 1929 & $\begin{array}{l}M_{s} 7.8 \\
M_{w} 7.8\end{array}$ & 10 & $\begin{array}{l}\text { Widespread catastrophic landslides; } \\
\text { extensive damage; surface faulting; } \\
17 \text { deaths, } 14 \text { due to landsliding (Isr). }\end{array}$ & [15], [29], [44] \\
\hline $\begin{array}{l}\text { (9) Hawke=s Bay } \\
\text { (Napier) }\end{array}$ & 3 Feb 1931 & $\begin{array}{l}M_{s} 7.8 \\
M_{w} 7.8\end{array}$ & 17 & $\begin{array}{l}\text { Widespread damage, surface faulting, } \\
\text { landslides; } 256 \text { deaths (none Isr). }\end{array}$ & [5], [17], GNS Files; \\
\hline (10) Wairoa & 16 Sep 1932 & $\begin{array}{l}M_{s} 6.9 \\
M_{w} 6.8\end{array}$ & 20 & $\begin{array}{l}\text { Damage in Gisborne and Wairoa; } \\
\text { significant landsliding. }\end{array}$ & {$[11],[17]$} \\
\hline (11) Pahiatua & 5 Mar 1934 & $\begin{array}{l}M_{s} 7.6 \\
M_{w} 7.4\end{array}$ & 15 & $\begin{array}{l}\text { Much landslide damage in } S \text { Hawkes } \\
\text { Bay and N Wairarapa; } 2 \text { deaths (not Isr). }\end{array}$ & {$[11],[17],[13]$} \\
\hline $\begin{array}{l}\text { (12) Masterton } \\
\text { (Wairarapa) }\end{array}$ & $\begin{array}{l}24 \text { Jun } 1942 \\
2 \text { Aug } 1942 \\
\end{array}$ & $\begin{array}{l}M_{s} 7.2 \\
M_{s} 7.0\end{array}$ & $\begin{array}{l}15 \\
43\end{array}$ & $\begin{array}{l}\text { Much damage in Wairarapa and } \\
\text { Wellington; many landslides. }\end{array}$ & {$[11]$} \\
\hline $\begin{array}{l}\text { (13) Lake Coleridge } \\
\text { (formeriy } M_{s} 6.2 \text { ) }\end{array}$ & 27 Jun 1946 & $M_{s}, M_{w} 6.4$ & 10 & Some minor landsliding of note & [11], [17] \\
\hline (14) Peria & 23 Dec 1963 & $M_{L} 4.9$ & 10 & Minor landsliding & {$[19]$} \\
\hline (15) Inangahua & 24 May 1968 & $\begin{array}{l}M_{s} 7.4 \\
M_{w} 7.2 \\
\end{array}$ & 10 & $\begin{array}{l}\text { Much damage; extensive and very large } \\
\text { landslides in Buller area; } 3 \text { deaths, } 1 \text { lsr }\end{array}$ & {$[4],[17]$} \\
\hline (16) Waiotapu & 15 Dec 1983 & $\begin{array}{l}M_{s} 4.6 \\
M_{w} 5.1\end{array}$ & 3 & Minor landslide effects generally & [11], [17] \\
\hline (17) Edgecumbe & 2 Mar 1987 & $\begin{array}{l}M_{s} 6.6 \\
M_{w} 6.5\end{array}$ & 6 & $\begin{array}{l}\text { Much damage, surface faulting; many } \\
\text { landslides and extensive liquefaction. }\end{array}$ & {$[11],[21],[37]$} \\
\hline (18) Weber & 13 May 1990 & $M_{s}, M_{w} \cdot 6.4$ & 11 & $\begin{array}{l}\text { Widespread minor landsliding in weak } \\
\text { Tertiary rocks; minor damage to roads }\end{array}$ & {$[11],[17],[45]$} \\
\hline $\begin{array}{l}\text { (19) Ormond } \\
\text { (formerly } M_{\llcorner} 6.3 \text { ) }\end{array}$ & 10 Aug 1993 & $\begin{array}{l}M_{s} 6.2 \\
M_{w} 6.2\end{array}$ & 39 & $\begin{array}{l}\text { Widespread minor landsliding in weak } \\
\text { Tertiary rocks; minor damage to roads }\end{array}$ & {$[17],[47],[48]$} \\
\hline $\begin{array}{l}\text { (20) Fiordland } \\
\text { (formerly } M_{L} 6.7 \text { ) }\end{array}$ & 10 Aug 1993 & $\begin{array}{l}M_{s} 7.0 \\
M_{w} 7.0\end{array}$ & 20 & $\begin{array}{l}\text { Sparsely distributed landsliding over a } \\
\text { wide area; generally small slides. }\end{array}$ & {$[17],[57]$} \\
\hline $\begin{array}{l}\text { (21) Arthur's Pass } \\
\text { (formerly } M_{L} 6.6 \text { ) }\end{array}$ & 18 Jun 1994 & $M_{w} 6.7$ & 4 & $\begin{array}{l}\text { Widespread landsliding in the Southern } \\
\text { Alps epicentral area }\end{array}$ & [17], [42], GNS Files \\
\hline (22) Arthur's Pass & 29 May 1995 & $M_{L} 5.5$ & 4 & Landslides affected road cuts and fills & {$[43]$} \\
\hline \multicolumn{6}{|c|}{$\begin{array}{ll}\text { NOTES: } \\
\text { 1. } & \text { Magnitude values are either: local }\left(M_{L}\right) \text {; surface wave }\left(M_{S}\right) \text {; mome } \\
\text { 2. } & \text { Centroid (centre of fault rupture surface) depths }(k m) \text { from Dowri } \\
\text { 3. } & \text { Files and other seismological and landslide data held by the Instit } \\
\text { 4. } & \text { The approximate size of landslides referred to in this paper are: }\end{array}$} \\
\hline
\end{tabular}


Because there are few published papers on MM intensity and earthquake-induced landslides in New Zealand, the Study Group were unable to establish well-defined landslide and ground failure criteria for the NZ 1991 Proposed scale. In the 1991 version it is suggested that in New Zealand major slides probably occur at MM8, and are general on steep slopes only at MM9 (the area of widespread landsliding has corresponded to about the MM9 isoseismal in several historic events). No environmental effects are listed for MM10, although it can be inferred that they would be similar to MM9 but more intense and widespread.

In the $1991 \mathrm{MM}$ scale revision, landsliding and ground damage criteria and effects were poorly defined because the Study Group found few data on which to base a revision of these environmental effects. To a large extent this view reflected the state of our historical earthquake records, and how past researchers have interpreted landslide effects in assigning intensities to New Zealand earthquakes. The 1997 study was therefore aimed at improving that situation by studying earthquake-induced landsliding during historical earthquakes in New Zealand.

Although landslide-related criteria are not referred to in the MM scale at intensities less than MM7, the study by Keefer (1984 a) clearly shows that earthquake-induced landslides do occur at intensities lower than MM7. The NZNSEE Study Group (1992) acknowledged that landslides can be caused by shaking intensities lower than MM7, but did not recognise the differences in landsliding that are caused by earthquakes of different magnitude and shaking intensities, or the potential uses of landslide data in MM intensity studies related to both historical and future earthquakes in New Zealand.

A revision of the New Zealand MM scale was undertaken by Dowrick (1996) following his earlier studies of New Zealand earthquakes (e.g., Dowrick, 1994). This revision resulted in improvements to structural damage criteria at MM6 to MM8, discussion of the influence of ground conditions on construction performance, and inclusion of structural criteria for MM10 to MM12, which were lacking from the 1991 version. Environmental response criteria (landslides) were generally unchanged, but were reintroduced for MM10 although not MM11 and MM12.

Prior to the 1997 study, the NZ 1996 version of the MM intensity scale was the most complete published version currently available. But like previous versions of the MM scale, it was also general and vague in places, and could not be used to assign intensities in areas where there are no buildings. In his study of the 1929 Murchison earthquake, Dowrick (1994) was unable to assign MM10 from building damage, although he suggested that shaking probably reached MM10 in the 'heavy' landslide zone close to the fault rupture where there were no buildings. Dowrick (1994) also suggested that the criteria for assigning intensity based on landslides need to be described in more detail in order to be reliable at MM8 and MM9, and ground classes that reflect landslide vulnerability, similar to those used for buildings, would benefit seismic hazard assessments.

The primary aims of the 1997 study were therefore to: (a) study the nature and extent of landsliding and other ground damage (sand boils, subsidence and lateral spreading due to soil liquefaction) caused by historical earthquakes in New Zealand; (b) determine relationships between landslide distribution and earthquake magnitude, epicentre, isoseismals, faulting, geology and topography; and (c) establish improved environmental response criteria in the MM Intensity Scale (N Z), and Ground Classes for assigning MM intensities and seismic hazard assessments in New Zealand. Although there is credible evidence that earthquakes have probably triggered many prehistoric landslides in New Zealand (as discussed later), the study was initially limited to historical earthquakes because much better data are available for those events.

\subsection{Study methods, data, and limitations}

The initial part of the 1997 study involved reviewing relevant overseas and NZ literature on earthquake-induced landsliding, followed by an extensive search of old newspapers, and some mapping and aerial photography of landslides caused by 22 historical earthquakes in New Zealand (Table 1). Maps of landslides associated with these earthquakes were prepared from information compiled in the data review, and supplemented by studies of aerial photos, topographic maps, and information from the Institute of Geological and Nuclear Sciences (GNS) database of large landslides. The location and extent of landsliding associated with these events was analysed in a geographic information system (GIS) and plotted on maps (at scales of 1:250,000 to $1: 400,000$ ), along with relevant seismicity data (earthquake epicentre, MM isoseismals, mainly from Downes 1995, and the distribution of aftershocks) and surface faulting information from both published and unpublished sources. The combined information now forms a computer-based national database of historical earthquake-induced landslides in New Zealand.

Figure 1 shows the locations, dates, and names of the historical earthquakes studied, along with the general extent of landsliding for the most important earthquakes. The inset map shows the epicentres of earthquakes $>$ M 5 that have occurred in New Zealand since 1840 . While the small scale of Figure 1 does not allow the detail of landslide locations to be seen, it does show the general distribution of historical earthquake-induced landsliding in New Zealand and its strong correlation with areas of high seismicity.

Where possible the data shown on individual landslide maps included: (a) precise and/or general landslide locations; (b) sites of known soil liquefaction (sand boils and lateral spreads); the main and total areas in which landslides occurred; (c) earthquake epicentre and isoseismals; (d) the zone of aftershocks; and (e) ground surface fault traces.

For the six most important earthquakes (Table 1, numbers 2 , $7,8,9,15,21$ ), tabulated data was presented on landslide type and size, distance from the epicentre, slope angle and type, failure direction relative to the epicentre, and geology. Comment on the social impact, such as the damage and number of deaths caused by landslides, was also included.

Data from the historical earthquakes were assessed and integrated to establish relationships and relative effects of seismic parameters and environmental factors (rock and soil types, geological structure, topography, climate, and inferred [winter or summer] groundwater conditions) on earthquakeinduced landsliding in New Zealand.

The most useful data for revising the environmental response criteria in the MM scale came from a few well documented earthquakes, such as Arthur's Pass 1929, Murchison 1929, 
Inangahua 1968, Edgecumbe 1987, Ormond 1993, and Arthur's Pass 1994. However, few of these earthquakes allowed a good comparison of environmental and structural MM criteria because most of the landsliding occurred in hilly areas where there are few buildings. It was not possible to describe landslides and ground damage caused by individual earthquakes in great detail in the nation-wide 1997 study.

The 1997 study had some limitations because the effects of many older earthquakes are poorly known and sparsely documented. For many older events, only approximate positions of individual slides and areas of known landsliding could be shown, and epicentre locations, magnitude estimates, and isoseismal maps are poorly constrained. When using aerial photos it was often necessary to make subjective judgements on whether individual landslides were formed by a particular earthquake or due to some other cause. Such assessments were generally based on the relative freshness of the landslide scar, growth of vegetation, historical photos, and written accounts in scientific papers and newspapers.

To illustrate the methodology used for the 1997 study and some general findings, an important earthquake study is discussed in the next section of the paper. The earthquake described is the 1929 Murchison (Buller) earthquake (Table 1, Number 8 ). This event caused the most extensive and catastrophic landslide damage of any historical earthquake in New Zealand, affecting a wide variety of rock types and terrain, and having significant social impact throughout the Buller and northwest Nelson area.

Data from the Murchison earthquake were also very important in developing the MM intensity relationships, ground classes, and earthquake-induced landslide hazard model discussed later. Landslides and ground damage effects of the Murchison earthquake were studied in greater detail after the 1997 study. Because these effects are referred to and used throughout this paper, they are described here rather than in a separate paper.

\section{1929 MURCHISON EARTHQUAKE STUDY}

\subsection{Earthquake location and character}

The $\mathrm{M}_{\mathrm{s}} 7.8$ Murchison (Buller) earthquake of 17 June 1929 caused widespread landsliding over about $4500 \mathrm{~km}^{2}$ of the mountains of northwest Nelson, mainly in an area extending $\sim 90 \mathrm{~km}$ north of the epicentre, but only $20 \mathrm{~km}$ to the south.
In terms of the extensive environmental damage and the number of deaths caused by landsliding (16), this event is New Zealand's most important historical earthquake. The total area affected by landsliding during the earthquake was $\sim 7000 \mathrm{~km}^{2}$

Figure 2 is a simplified map of the earthquake-affected area, showing the locations of landslides, liquefaction effects, and isoseismals attributed to the Murchison earthquake. Data on the main landslides are summarised in Table 2, and typical slides are shown in Figures 3-8.

The earthquake was associated with ground surface fault rupture on the White Creek Fault about $11 \mathrm{~km}$ west of Murchison in the upper Buller Gorge. The fault was best exposed on the road (SH6) through the gorge, where the east side of the fault was uplifted vertically by $\sim 4.5 \mathrm{~m}$, and displaced horizontally (to the north) by $\sim 2.2 \mathrm{~m}$. It was predominantly a reverse faulting event. The White Creek Fault dips steeply $\left(70^{\circ}-80^{\circ}\right)$ to the east, with the rupture striking almost north-south (Berryman, 1980). The fault break has been traced northwards across steep bush-covered country for $\sim 8 \mathrm{~km}$ and $\sim 5 \mathrm{~km}$ to the south (Figure 2). An earlier study (Dowrick (1994) suggested that the fault rupture might have extended $30-40 \mathrm{~km}$ further north. However, because of the steep bush-covered terrain, both the full extent of the surface fault break and the exact location of the earthquake epicentre remain uncertain. These issues are discussed later.

The epicentre for the earthquake $\left(41.7^{\circ} \mathrm{S}, 172.2^{\circ} \mathrm{E}\right)$ has usually been located at the surface fault break in the Buller Gorge (Figure 2). However, that position is somewhat doubtful. The nominal epicentral area of the 1929 earthquake near Murchison was lightly populated $(\sim 300)$, and hence had only 100 or so buildings, and was surrounded by steep bushcovered mountains that are prone to ground damage during earthquakes.

The effects of the earthquake were therefore dominated by landslides rather than damage to buildings (Dowrick, 1994; Henderson, 1937). This is emphasised by the knowledge that, of the 17 deaths caused by the earthquake, landslides killed 14 people, and 2 miners were killed in coal collapses at Seddonville (Table 2). The other death resulted from insulin deprivation, but was indirectly related to landsliding because landslides blocking roads and damage to bridges cut off medical supplies to the earthquake area. 


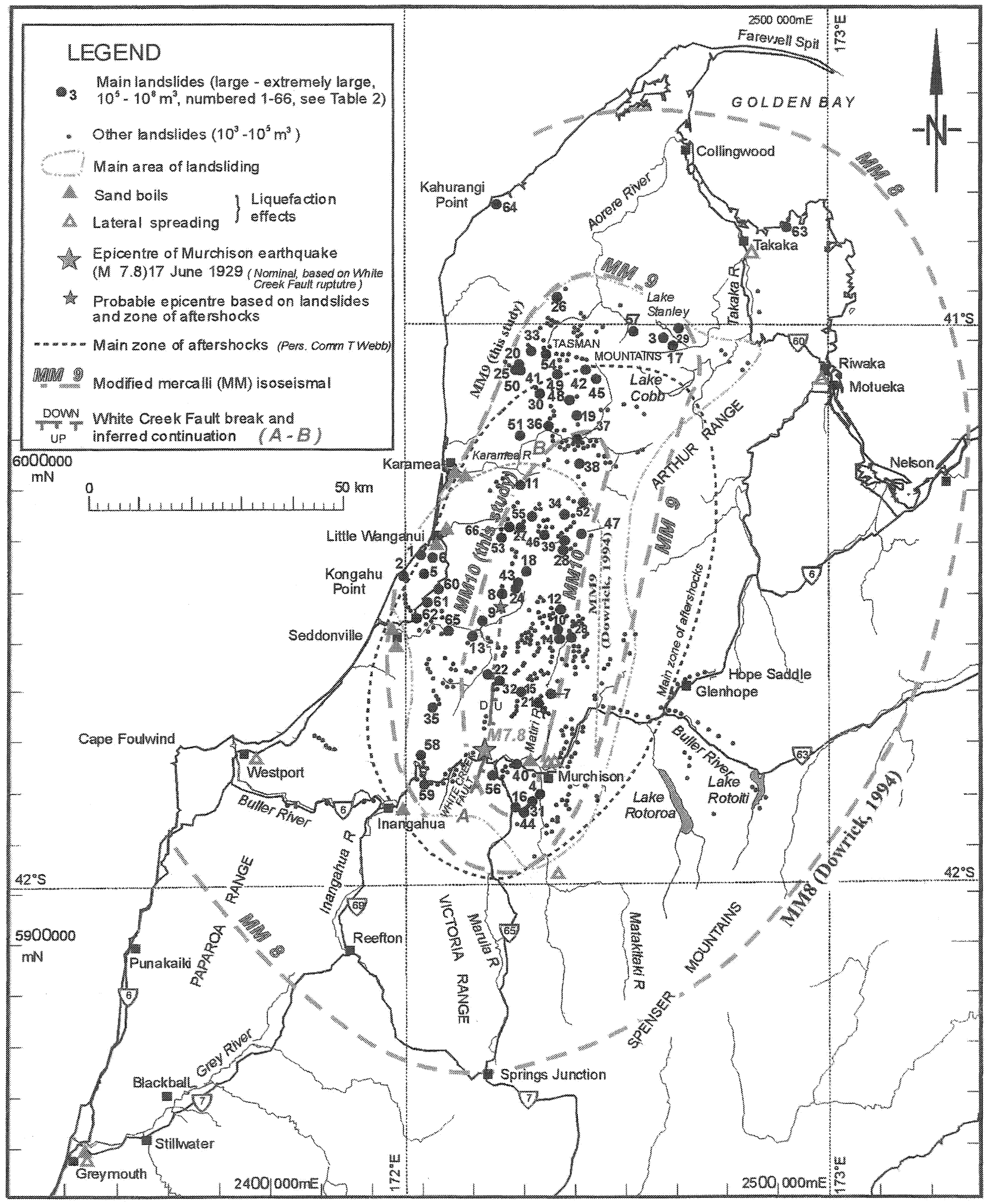

Figure 2. Map showing the locations of landslides and liquefaction effects caused by the 1929 Murchison earhquake. The main slides (shown by large nuwbered dots) are those listed in Table 2 , while other known significant slides are shown by snaller dots. It was not possible to show the great many smaller, superficial slides and rock falls that occurred within the nain areas of landsliding (dash-dot line). Landslide distribution has been used to redefine the MMP isoseisnal for this earhquake (more extensive than drown by Dowrick, 1994) and establish the MM10 isoseismal. The probable $75 \mathrm{~km}$ fault rupture $(A-B)$ is the length of the newly defined MMIO zone. 
Table 2. Main landslides caused by the 17 June 1929 Murchison earthquake

\begin{tabular}{|c|c|c|c|c|c|}
\hline $\begin{array}{l}\text { LANDSLIDE NUMBER (\#) } \\
\text { And NAME [1] }\end{array}$ & $\begin{array}{l}\text { DISTANCE } \\
\text { FROM } \\
\text { EPICENTRE }\end{array}$ & $\begin{array}{l}\text { APPROX } \\
\text { VOLUME } \\
\left(\times 10^{6} \mathrm{~m}^{3}\right)\end{array}$ & $\begin{array}{l}\text { FAILURE } \\
\text { TYPE [2] }\end{array}$ & $\begin{array}{l}\text { SLOPE } \\
\text { ANGLE/ } \\
\text { DIR [3] }\end{array}$ & $\begin{array}{l}\text { LITHOLOGY [4], SLOPE TYPE [5]; } \\
\text { DIP/DIR OF GEOL STRUCTURE [6]; } \\
\text { DRAINAGE [7] \& SOCIAL EFFECTS [8] }\end{array}$ \\
\hline (1) Little Wanganui Head & $41 \mathrm{~km}, \mathrm{NNW}$ & 210 & $\begin{array}{l}\text { DSR/SL,ROT } \\
\text { (Tran/rot) }\end{array}$ & $20^{\circ} / 315^{\circ}$ & Tert sst/calc mst; esc, $g(E)$ \\
\hline (2) Whitecliffs (Kongahu Pt) & 39 km, NNW & 120 & DSR/ROT & $50^{\circ} / 315^{\circ}$ & Tert sst/calc mst; esc, $g(E)$ \\
\hline (3) Stanley (upper) & $90 \mathrm{~km}, \mathrm{NNE}$ & 18 & DR/AV & $30^{\circ} / 020^{\circ}$ & Pal cong/volcs; ssl, s(E); Idl \\
\hline (4) Matakitaki (Busch Slip) & $14 \mathrm{~km}, \mathrm{SE}$ & 18 & DSR/SL,AV & $20^{\circ} / 090^{\circ}$ & Tert sst/mst; dsl, s(E); d/ldl; 4 deaths \\
\hline (5) Falls Creek & 38 km, NNW & 16 & SR/SL & $15^{\circ} / 075^{\circ}$ & Tert sst/mst; dsl; m(E); Idl \\
\hline (6) Glasseye & $41 \mathrm{~km}, \mathrm{NNW}$ & 15 & DSR/SL & $17^{\circ} / 060^{\circ}$ & Tert sst/mst; dsl, m(E); Idl \\
\hline (7) Matiri (lower) & $17 \mathrm{~km} \mathrm{NE}$ & 12 & $D R / F, A V$ & $40^{\circ} / 280^{\circ}$ & Tert sst/mst; dsl, s $(W) ; \quad$ ldl \\
\hline (8) Marina & $32 \mathrm{~km} \mathrm{~N}$ & 10.8 & DR/AV & $32^{\circ} / 090^{\circ}$ & Granite; Idl \\
\hline (9) Dora & $26 \mathrm{~km} \mathrm{~N}$ & 9 & DSR/SL & $31^{\circ} / 110^{\circ}$ & Tert sst/mst; dsl, m(E); Idl \\
\hline (10) Matiri (upper, Rt Br) & $29 \mathrm{~km} \mathrm{NE}$ & 7.2 & DR/R,AV & $34^{\circ} / 090^{\circ}$ & Tert Ist; dsI, m(E); Idl \\
\hline (11) Kakapo/Haystack & $53 \mathrm{~km} \mathrm{~N}$ & 5.4 & DR/AV & $30^{\circ} / 225^{\circ}$ & Tert sst/mst; dsl, m(E); d/Idl \\
\hline (12) Hurricane (L Janette) & $32 \mathrm{~km}$ NNE & 5.4 & DR/AV & $40^{\circ} / 090^{\circ}$ & Tert Ist; esc, m(ESE); Idl \\
\hline (13) Lake Perrine & $24 \mathrm{~km} \mathrm{~N}$ & 5 & DR/F,SL & $22^{\circ} / 020^{\circ}$ & Tert Ist/mst; dsI, m(E); d/ldl \\
\hline (14) Matiri (Right Branch) & $28 \mathrm{~km} \mathrm{NNE}$ & 5 & DR/AV & $34^{\circ} / 045^{\circ}$ & Tert mst/lst; dsl, m(E); d/ldl \\
\hline (15) Matiri (West Branch) & $14 \mathrm{~km}$ NNE & 4.8 & DR/AV & $45^{\circ} / 090^{\circ}$ & Tert mst; esc, m(WNW) \\
\hline (16) Maruia Falls (Gibson) & $12 \mathrm{~km} \mathrm{SSE}$ & 4.5 & DSR/F,SL & $25^{\circ} / 270^{\circ}$ & Tert sst/mst; dsl, m(W); d/ldl; 4 deaths \\
\hline (17) Stanley (lower) & $90 \mathrm{~km} \mathrm{NNE}$ & 4.5 & DR/AV & $30^{\circ} / 050^{\circ}$ & Pal cong/volcs; dsl, s(SE); d/ldl \\
\hline (18) Allen & $37 \mathrm{~km} \mathrm{NNE}$ & 4.2 & DR/AV & $34^{\circ} / 080^{\circ}$ & Granite; Idl \\
\hline (19) Beautiful & $69 \mathrm{~km}$ NNE & 4.1 & DR/AV & $34^{\circ} / 080^{\circ}$ & Granite; Idl \\
\hline (20) Elmer & $77 \mathrm{~km} \mathrm{~N}$ & 4 & DR/AV & $37^{\circ} / 090^{\circ}$ & Granite; Idl \\
\hline (21) Matiri (Rain Peak) & $14 \mathrm{~km} \mathrm{NE}$ & 4 & DR/AV & $30^{\circ} / 220^{\circ}$ & Granite; Idl \\
\hline (22) Goat & $26 \mathrm{~km} \mathrm{~N}$ & 3.8 & DR/AV & $30^{\circ} / 135^{\circ}$ & Tert sst/mst; dsl, m(NE) \\
\hline (23) Luna Slips & $43 \mathrm{~km}$ NNE & 3.6 & DR/AV & $35^{\circ} / 030^{\circ}$ & Granite; d/ldl \\
\hline (24) Johnson & $33 \mathrm{~km} \mathrm{~N}$ & 3.2 & DR/AV & $28^{\circ} / 090^{\circ}$ & Granite; $d / / d l$ \\
\hline (25) Rubble (upper) & $75 \mathrm{~km} \mathrm{~N}$ & 3 & DR/AV & $40^{\circ} / 070^{\circ}$ & Granite; Idl \\
\hline (26) Gouland & $91 \mathrm{~km} \mathrm{~N}$ & 3 & DR/AV & $25^{\circ} / 230^{\circ}$ & Granite \\
\hline (27) Tangent & $46 \mathrm{~km} \mathrm{~N}$ & 2.7 & DR/AV & $30^{\circ} / 290^{\circ}$ & Granite; Idl \\
\hline (28) Matiri (Lake, upper) & $29 \mathrm{~km} \mathrm{NE}$ & 2.7 & DR/AV many & $30^{\circ} / 250^{\circ}$ & Tert Ist/mst; dsI, s(W); Idl \\
\hline (29) Lindsay (lower) & $80 \mathrm{~km} \mathrm{NNE}$ & 2.5 & DR/AV & $32^{\circ} / 055^{\circ}$ & Pal cong/volcs; dsl, s(E); Idl \\
\hline (30) $\mathrm{McNabb}$ & $72 \mathrm{~km} \mathrm{~N}$ & 2.5 & DR/AV & $35^{\circ} / 090^{\circ}$ & Granite; Idl \\
\hline (31) Johnson Creek & $13 \mathrm{~km} \mathrm{SE}$ & 2 & SDR/SL,AV & $25^{\circ} / 085^{\circ}$ & Tert Ist/mst; dsl, $g(E)$ \\
\hline (32) Stern & $14 \mathrm{~km} \mathrm{SE}$ & 2 & DR/AV & $30^{\circ} / 225^{\circ}$ & Tert Ist/mst; dsI, s(SE) \\
\hline (33) Ugly (upper) & $79 \mathrm{~km} \mathrm{~N}$ & 2 & DR/AV & $32^{\circ} / 300^{\circ}$ & Granite; d/ldl \\
\hline (34) Mercury & $50 \mathrm{~km} \mathrm{NNE}$ & 2 & DR/AV & $40^{\circ} / 010^{\circ}$ & Granite; $d / l d l$ \\
\hline (35) Ngakawau & $13 \mathrm{~km} \mathrm{NW}$ & 1.8 & DR/AV & $27^{\circ} / 270^{\circ}$ & Greywacke; dsI, s(W); Idl \\
\hline (36) Ferris & $66 \mathrm{~km} \mathrm{NW}$ & 1.8 & DR/AV & $39^{\circ} / 100^{\circ}$ & Granite; Idl \\
\hline \multicolumn{6}{|l|}{ Continued next page. } \\
\hline
\end{tabular}


Table 2 continued

\begin{tabular}{|c|c|c|c|c|c|}
\hline $\begin{array}{c}\text { LANDSLIDE NUMBER (\#) } \\
\text { and NAME) [1] }\end{array}$ & $\begin{array}{l}\text { DISTANCE } \\
\text { FROM } \\
\text { EPICENTRE }\end{array}$ & $\begin{array}{l}\text { APPROX } \\
\text { VOLUME } \\
\left(\times 10^{6} \mathrm{~m}^{3}\right)\end{array}$ & $\begin{array}{l}\text { FAILURE } \\
\text { TYPE [2] }\end{array}$ & $\begin{array}{l}\text { SLOPE } \\
\text { ANGLE / } \\
\text { DIR [3] }\end{array}$ & $\begin{array}{l}\text { LITHOLOGY [4], SLOPE TYPE [5]; } \\
\text { DIP/DIR OF GEOL STRUCTURE [6]; } \\
\text { DRAINAGE [7] \& SOCIAL EFFECTS [8] }\end{array}$ \\
\hline (37) Garribaldi & $64 \mathrm{~km} \mathrm{NNE}$ & 1.8 & DR/AV & $45^{\circ} / 340^{\circ}$ & Tert/granite; esc; Idl \\
\hline (38) Silvermine & $60 \mathrm{~km} \mathrm{NNE}$ & 1.8 & DR/AV & $34^{\circ} / 110^{\circ}$ & Tert Ist/sst; dsl, esc, g(S) \\
\hline (39) Luna & $44 \mathrm{~km} \mathrm{NNE}$ & 1.8 & DR/AV & $40^{\circ} / 190^{\circ}$ & Granite \\
\hline (40) Sphinx (Fern Flat) & $7 \mathrm{~km}$ ESE & 1.7 & $\mathrm{DR} / \mathrm{F}, \mathrm{AV}$ & $50^{\circ} / 000^{\circ}$ & Tert calc mst; esc, m(SE); d/ldl \\
\hline (41) Ugly (lower) & $76 \mathrm{~km} \mathrm{~N}$ & 1.6 & DR/AV & $50^{\circ} / 070^{\circ}$ & Granite \\
\hline (42) Discovery & $79 \mathrm{~km} \mathrm{NNE}$ & 1.6 & DR/AV & $35^{\circ} / 190^{\circ}$ & Semi-schist; dsl, s(E); Idl \\
\hline (43) Gorgeous & $34 \mathrm{~km} \mathrm{~N}$ & 1.5 & DR/AV & $30^{\circ} / 070^{\circ}$ & Granite; d/ldl ? \\
\hline (44) Hutchison & $15 \mathrm{~km} \mathrm{SE}$ & 1.5 & DR/AV & $28^{\circ} / 280^{\circ}$ & Tert Ist/mst; dsl, m(NW) \\
\hline (45) Downey & $77 \mathrm{~km} \mathrm{NNE}$ & 1.5 & DR/AV & $35^{\circ} / 170^{\circ}$ & Semi-schist; dsl, $s(E) ; d / / d l$ \\
\hline (46) Kakapo Saddle & $44 \mathrm{~km} \mathrm{NNE}$ & 1.5 & DR/AV & $39^{\circ} / 045^{\circ}$ & Granite \\
\hline (47) Moonstone & $48 \mathrm{~km} \mathrm{NE}$ & 1.5 & DR/AV & $40^{\circ} / 080^{\circ}$ & Granite; Idl \\
\hline (48) Barfoot & $72 \mathrm{~km} \mathrm{NNE}$ & 1.4 & DR/AV & $40^{\circ} / 270^{\circ}$ & Granite; Idl \\
\hline (49) Beautiful (upper) & $76 \mathrm{~km} \mathrm{NNE}$ & 1.2 & DR/AV & $30^{\circ} / 040^{\circ}$ & Granite \\
\hline (50) Rubble (lower) & $75 \mathrm{~km} \mathrm{~N}$ & 1 & DR/AV & $34^{\circ} / 070^{\circ}$ & Granite \\
\hline (51) Greys & $63 \mathrm{~km} \mathrm{~N}$ & 1 & DR/AV & $30^{\circ} / 250^{\circ}$ & Granite \\
\hline (52) Venus & $53 \mathrm{~km} \mathrm{NNE}$ & 0.9 & DR/AV & $35^{\circ} / 010^{\circ}$ & Granite \\
\hline (53) Anaconda & $43 \mathrm{~km} \mathrm{~N}$ & 0.8 & DR/AV & $30^{\circ} / 270^{\circ}$ & Greywacke; ssl, m(E) \\
\hline (54) Aorere Saddle & $80 \mathrm{~km} \mathrm{~N}$ & 0.8 & DR/AV & $32^{\circ} / 280^{\circ}$ & Granite \\
\hline (55) Kakapo & $47 \mathrm{~km} \mathrm{~N}$ & 0.8 & DR/AV & $31^{\circ} / 070^{\circ}$ & Granite \\
\hline (56) Maruia Valley & $4 \mathrm{~km} \mathrm{SE}$ & 0.7 & $\mathrm{DR} / \mathrm{F}, \mathrm{SL}$ & $28^{\circ} / 090^{\circ}$ & Tert sst/mst; d/ldl; 2 deaths \\
\hline (57) Burgoo & $91 \mathrm{~km} \mathrm{~N}$ & 0.6 & DR/AV & $40^{\circ} / 270^{\circ}$ & Semi-schist; dsl, s(W); d/ldl \\
\hline (58) New Creek & $15 \mathrm{~km} \mathrm{~W}$ & $<0.7$ & CR/ROT & $10^{\circ} / 280^{\circ}$ & Tert mst; dsl, s(E) \\
\hline (59) Buller River & $13 \mathrm{~km} \mathrm{SW}$ & $<0.7$ & DR/AV & $38^{\circ} / 045^{\circ}$ & w/granite, regolith; d/ldl \\
\hline (60) SH 67 Glasseye Ck & $34 \mathrm{~km} \mathrm{NNW}$ & $<0.5$ & $D R / S L, F$ & $34^{\circ} / 315^{\circ}$ & Tert mst/sst; dsl, s(NW) \\
\hline (61) SH 67 Corbyvale & $32 \mathrm{~km} \mathrm{NW}$ & $<0.5$ & DR/SL & $35^{\circ} / 310^{\circ}$ & Tert mst/sst; dsl, s(NW) \\
\hline (62) SH 67 Karamea & $30 \mathrm{~km} \mathrm{NW}$ & $<0.5$ & DR/R,SL & $35^{\circ} / 270^{\circ}$ & Tert sst/st; esc, $g(E)$ \\
\hline (63) Tarakohe (Cement & $120 \mathrm{~km} \mathrm{NE}$ & $<0.1$ & $\mathrm{DR} / \mathrm{F}$ & $75^{\circ} / 015^{\circ}$ & Tert Ist; 1 death \\
\hline (64) Kahurangi & $109 \mathrm{~km} \mathrm{~N}$ & $<0.5$ & DR/SL & $15^{\circ} / 000^{\circ}$ & Tert sst/mst/lst; dsl, g(NW) \\
\hline (65) Mokihinui Gorge & $25 \mathrm{~km} \mathrm{~N}$ & $<0.5$ & DR/F,SL & $37^{\circ} / 000^{\circ}$ & Granite/gwke; dsl, s; 2 deaths \\
\hline (66) Little Wanganui & $44 \mathrm{~km} \mathrm{~N}$ & c. 0.5 & DR/F,AV & $40^{\circ} / 045^{\circ}$ & Granite; d/ldl \\
\hline \multicolumn{6}{|c|}{ 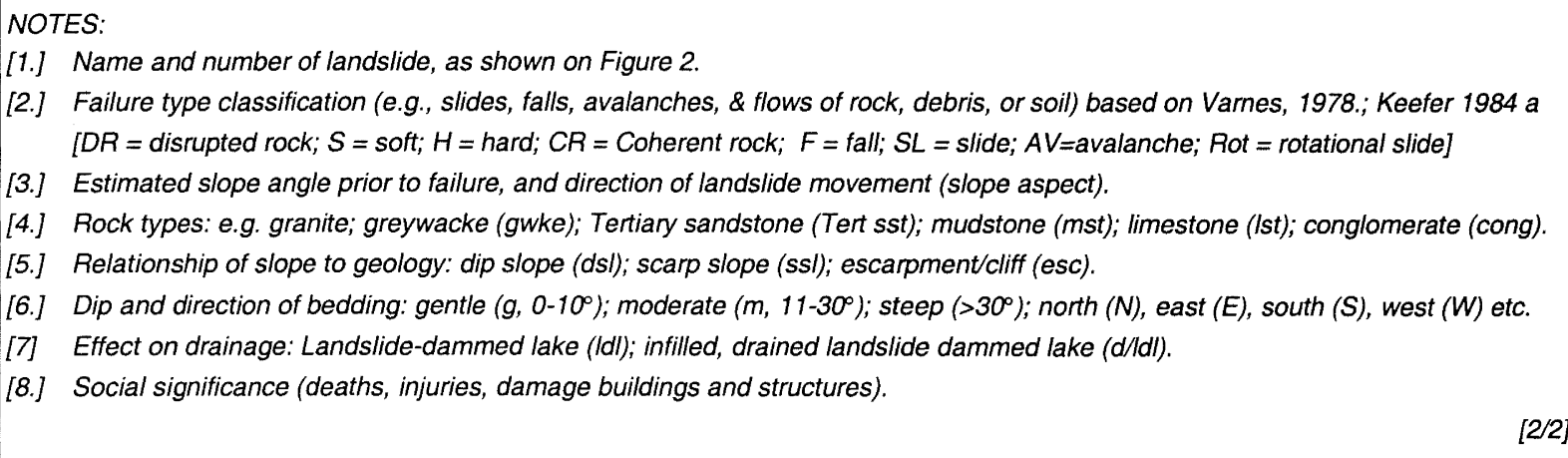 } \\
\hline
\end{tabular}




\subsection{Building damage and felt intensities}

Dowrick (1994) reports that the earthquake caused considerable damage to buildings in Murchison (MM9), Westport (MM8), Greymouth (MM7), and Nelson (MM8), as well as nearby small towns such as Reefton (MM8), Karamea (MM8 and 9), Seddonville (MM8), and Granity (MM8). It is notable that, while the shaking was very severe, even at distances of up to $\sim 100 \mathrm{~km}$ from the epicentre, no building collapsed completely in the main shock due to ground shaking, although Hodgson's store in Murchison was close to collapse and some buildings were severely damaged (e.g., Westport Post Office). In most cases, however, the main damage to buildings was loss or cracking of chimneys and other masonry works, and some houses were shaken off their piles. Damage to public utilities (electricity, water and gas supply, sewerage, and telephone systems) was modest, but caused disruption of some services for several days in Murchison (Dowrick, 1994). The Murchison power station was out of commission for several months due to damage to the water race, holding dam, and mechanical plant.

\subsection{Earthquake-induced landsliding}

Figure 2 shows the distribution of the main landslides that occurred during the Murchison earthquake, as determined from aerial photographs, topographic maps, and photos and descriptions in historical publications and newspapers. Terrain in the earthquake-affected area is mostly very steep, bush-covered and mountainous, and was predisposed to landsliding by widespread erosion and weathering, combined with a thick cover of slope debris saturated by a particularly wet winter (Henderson, 1937). The earthquake triggered more than 50 very large landslides with volumes ranging from about 1 to 200 million $\mathrm{m}$, and many others of several hundred thousand cubic metres. The main landslides are listed (numbered and named) in Table 2, and their approximate locations are shown in Figure 2.

The mountains of northwest Nelson contain many different rock types, which were affected by landsliding to varying degrees. Large landslides occurred in granitic and older sedimentary rocks, Tertiary mudstone, sandstone, limestone, calcareous siltstone, conglomerate and Pleistocene gravels (Table 2). As expected, steeper slopes such as cliffs and escarpments, narrow ridges, spur ends, and terrace edges were most affected.

Rock strength and discontinuities (bedding and joints) strongly influenced the types and size of slope failures. Most of the larger 1929 landslides are still visible in the landscape, appearing as bare or scrub-covered scars, or areas of rock debris partly covered with regenerating vegetation. Both on the ground and air photos the 1929 landslides are clearly distinguishable from the bare scars of those caused by the 1968 Inangahua earthquake, and also the bush-covered prehistoric landslides in the area.

Only the larger earthquake-induced landslides $\left(>100,000 \mathrm{~m}^{3}\right)$ are listed in Table 2. These failures have a total slide debris volume of about $0.56 \times 10^{9} \mathrm{~m}^{3}$, and involved predominantly bedrock and surficial materials. In addition to these failures there were also several thousand smaller $\left(\sim 1-20 \times 10^{3} \mathrm{~m}^{3}\right)$ regolith slides. For example, in the central earthquakeaffected area (between the Matiri and Wangapeka rivers) Pearce and O'Loughlin (1985) estimated that $\sim 3000-4000$ slides might have occurred. The total number of landslides over the entire affected area may therefore have been close to 10,000 . Based on an overall landslide-affected area of 5000 $\mathrm{km}^{2}$, Adams (1980) estimated the total volume of landslide debris from the 1929 earthquake to be $\sim 1.3 \times 10^{9} \mathrm{~m}^{3}$. However, given the greater landslide-affected area estimated in the 1997 study $\left(\sim 7000 \mathrm{~km}^{2}\right)$, the overall volume of landslide debris formed during the earthquake could be as high as $2 \times 10^{9} \mathrm{~m}^{3}\left(\sim 2 \mathrm{~km}^{3}\right)$. This is considerably more than for any other historical New Zealand earthquake.

Significant aspects of the landsliding and ground damage in affected areas are summarised in Table 3. Earthquakeinduced landslides caused severe damage and closure of roads, with major damage in the upper Buller Gorge, Matakitaki valley, Maruia Saddle, and Karamea Bluff (Corbyvale road). Road embankments subsided in many places in the epicentral area as distant as Greymouth, Takaka, and Collingwood, more than $120 \mathrm{~km}$ away. Henderson (1937) reports that slumping of bridge approaches and displaced piers caused considerable damage in many places (e.g., bridges across Matakitaki River at Murchison, Newton River, Lyell Creek, and Little Wanganui River), cutting access and isolating communities.

Landslides were largest and most common on steep slopes $\left(20^{\circ}-50^{\circ}\right)$ formed on dip slopes in Tertiary sandstones and mudstones, and in weathered, well-jointed granite (see Table 2). Many of these slides (well described by Henderson, 1937) were particularly catastrophic, being responsible for 10 of the 14 deaths caused by landsliding. In these cases the victims were occupants of houses built in river valleys on relatively flat ground, but close (100-500 m or less) to the foot of steep and high valley slopes. Long runout of landslide debris across the valley floor destroyed several houses on relatively flat ground, killing or injuring the occupants. 
Table 3. Damage caused by landslides during the 1929 Murchison earthquake

\begin{tabular}{|c|c|}
\hline Areas Affected & Summary of Landsliding and Ground Damage \\
\hline $\begin{array}{l}\text { Buller River area up to } 15 \mathrm{~km} \text { west, and } \\
\text { north along the White Creek Fault. }\end{array}$ & $\begin{array}{l}\text { Landslides large and numerous. Three roadmen were injured by } \\
\text { landslide debris in the Lyell area, and one (Tom Welch) later died. Many } \\
\text { very large slips in granite north along White Creek fault trace in upper } \\
\text { Newton River. Fewer slips south along fault for several km. The road } \\
\text { (SH 6) through the upper Buller Gorge between Murchison and Inangahua } \\
\text { was almost totally destroyed by huge slips in many places, some } 500 \text { to } \\
600 \mathrm{~m} \text { wide. Damage to the road took } 22 \text { months to repair. }\end{array}$ \\
\hline $\begin{array}{l}\text { Areas further west, north and } \\
\text { northwestern area between the Buller } \\
\text { and Karamea rivers to the west coast. }\end{array}$ & $\begin{array}{l}\text { Very many small to very large slips in mountains to the west coast. } \\
\text { Westport badly affected by ground fissures and slumping of road fills and } \\
\text { cuts. Road through the lower Buller Gorge from Westport to Inangahua } \\
\text { blocked by slips for a few days. Large landslide-dams of granite and } \\
\text { Tertiary limestone and mudstone formed in several main valleys } \\
\text { (Karamea, Mokihinui, Little Wanganui) and their tributaries. Two } \\
\text { prospectors (Mr Russell and his son) buried by large slip in the Mokihinui } \\
\text { Gorge. The Glasgow Range escarpment and road from Westport to } \\
\text { Karamea was badly damaged by large slips between Seddonville and } \\
\text { Corbyvale. Two miners were killed by falls in mines at Seddonville. } \\
\text { Settlements at Seddonville and Little Wanganui flooded by bursting of } \\
\text { landslide-dams during floods several weeks after the earthquake. Two } \\
\text { extremely large slides ( }>100 \text { million } \mathrm{m}^{3} \text { ) on the coastal cliffs between } \\
\text { Kongahu Point and Little Wanganui. }\end{array}$ \\
\hline $\begin{array}{l}\text { East of White Creek Fault to Murchison } \\
\text { (including the Buller valley, lower } \\
\text { Matiri, Matakitaki and Maruia valleys). }\end{array}$ & $\begin{array}{l}\text { Area very strongly shaken with many large landslides in the Matiri, } \\
\text { Matakitaki, Maruia, Mangles, and Buller valleys, and landslide-dams } \\
\text { formed in several places (Matakitaki, Maruia, Fern Flat in Buller etc.). The } \\
\text { Matiri valley was scarred 'from end to end' by vast slips from scarps } \\
\text { bordering the Thousand Acres Plateau, while in the lower Matiri the river } \\
\text { was dammed and at least one house destroyed by landslides. Large } \\
\text { landslides near Murchison killed } 10 \text { people - four in the Matakitaki valley, } \\
\text { and six in the Maruia valley. Roads in the Maruia and Matakitaki valleys, } \\
\text { and the Maruia Saddle road were closed by slips. Southernmost large } \\
\text { landslide in area was } 20 \mathrm{~km} \text { south of Murchison (Old Man of Buller). }\end{array}$ \\
\hline $\begin{array}{l}\text { Further east and northeast: Owen } \\
\text { River, Glenhope, and upper Buller } \\
\text { River to Lake Rotoiti. }\end{array}$ & $\begin{array}{l}\text { Road from Owen to Glenhope and Hope Saddle badly damaged by slips. } \\
\text { Road from Kawatiri to St Arnaud "strewn with boulders and slope debris". } \\
\text { "Huge masses of hillside reported to have slipped into Lake Rotoiti from } \\
\text { the Mt Robert Ridge". Some slides in the Howard valley. }\end{array}$ \\
\hline $\begin{array}{l}\text { Further North: Kahurangi Point, Cobb- } \\
\text { Takaka - Riwaka area. }\end{array}$ & $\begin{array}{l}\text { Kahurangi Point lighthouse area badly shaken, landslide demolished the } \\
\text { keeper's house. Very large rock avalanches in Tasman Mountains } \\
\text { formed landslide-dams (Stanley, Lower Lindsay). Several slips in the } \\
\text { Takaka valley. Sand and water ejections in Riwaka/Motueka area. Large } \\
\text { rock fall from cliffs at the Golden Bay Cement Works at Tarakohe killed an } \\
\text { engineer (Arthur Stubbs) in the powerhouse. }\end{array}$ \\
\hline $\begin{array}{l}\text { South-southwest: Greymouth to } \\
\text { Reefton and surrounding area. }\end{array}$ & $\begin{array}{l}\text { Very large rock fall at Cobden Quarry near Greymouth. Some roads } \\
\text { around Reefton blocked by slips. Railway lines and bridges damaged by } \\
\text { slips and embankment slumping (Hokitika-Greymouth, Brunner, Stillwater, } \\
\text { Moana). Ground fissures, sand and water ejections around Greymouth } \\
\text { (lateral spreading and sand boils). Small rockfalls in coal mines caused } \\
\text { minor injuries but no deaths. }\end{array}$ \\
\hline \multicolumn{2}{|c|}{$\begin{array}{l}\text { NOTES: Data mainly from (1) Henderson (1937); (2) Evening Post Newspapers (17-26 June 1929), and (3) "Stories of } \\
\text { Murchison Earthquake } 17^{\text {th }} \text { June, 1929", collected and published by The Murchison District Historical and Museum Society } \\
\text { Inc, June } 1999 .\end{array}$} \\
\hline
\end{tabular}




\subsubsection{Significant landslides}

The Matakitaki Landslide (4, Table 2) occurred on the west side of the Matakitaki valley, about $5 \mathrm{~km}$ south of Murchison. This was a deep-seated rock slide in Tertiary sandstones and mudstone, which dipped $30-40^{\circ}$ east towards the valley floor (Figure 3). During failure the landslide debris $(\sim 18$ million $\mathrm{m}^{3}$ and up to $50 \mathrm{~m}$ thick) became highly fragmented and travelled as a debris flow $\sim 1.2 \mathrm{~km}$ east across the valley floor. Landslide debris overwhelmed the Busch and Morel homesteads on the east side of the river, and killed four people (Mrs Busch, her son and daughter, and Charlie Morel). The Busch's house was completely buried by the landslide (along with at least 27 cows), while the upper story of the Morel's house was transported $\sim 50-100 \mathrm{~m}$ across the valley floor. Landslide debris dammed the Matakitaki River to a depth of about $25 \mathrm{~m}$, forming a lake (Matakitaki Lake) that extended $5 \mathrm{~km}$ up valley. The lake lasted almost 10 years, but was eventually washed out during a flood in the late 1930 s, surprisingly without causing significant damage downstream.

Six more people died in a similar fashion in the lower Maruia valley $\sim 12 \mathrm{~km}$ west of Murchison. The Maruia Falls Landslide (16 Table 2) killed four people (Mrs Gibson, her son, Leo Westbrook, and Miss Ferguson). In this failure, about 4.5 million $\mathrm{m}^{3}$ of rock on the east side of the valley collapsed from a spur of west-dipping Tertiary sandstones, burying the Gibson homestead under $\sim 60 \mathrm{~m}$ of rock debris (Figure 4), and damming the Maruia River for several days. The Maruia Falls were formed shortly after the earthquake, when the river was diverted from its course by the landslide and exhumed an old riverbank formed by a band of hard sandstone (Suggate, 1988). Another large landslide occurred further down the Maruia valley at Ariki, where a spur of Tertiary sandstone and mudstone on the west side of the valley collapsed (56, Holman Landslide, Table 2). Landslide debris destroyed the Holman homestead, killing Mrs Holman and her daughter, and dammed the Maruia River for two days. Several other very large dip-slope landslides occurred throughout the affected area, for example, Falls Creek (5) and Glasseye (6) slides near Little Wanganui (Figure 2), but these had little social impact.

There were also many large rock falls from Tertiary limestone and calcareous siltstone scarps in the Murchison area. Possibly the most significant of these failures was the Sphinx landslide (40), which dammed the Buller River at Fern Flat for several days. Similar escarpment failures landslides occurred on the Karamea Bluffs (62) closing the road to Seddonville for several weeks. Many large rock falls also occurred in the Matiri valley $(10,12,14,15,28)$ along steep scarps bordering the Thousand Acres Plateau, and rock slides added to the landslide-dam impounding Lake Matiri (Figure 5).
Coastal cliffs north of Westport were also substantially affected by slope failures, with many rock falls, and extremely large $\left(>50\right.$ million $\left.\mathrm{m}^{3}\right)$ rotational slides formed at Little Wanganui Head (1), and another at Whitecliffs (2) just north of Kongahu Point, where a large area of beach was uplifted on the slide toe (Figure 6). Further north, a large rock slide occurred at Kahurangi Point (64), $109 \mathrm{~km}$ northwest of the epicentre, destroying the lighthouse keeper's house. In another coastal cliff failure near Takaka $(\sim 120 \mathrm{~km}$ north of the epicentre) an engineer (Arthur Stubbs) was killed by a fall of large limestone blocks (63) at the Tarakohe Cement Works (Figure 7).

The two largest landslides (1 and 2 ) occurred in gently dipping Tertiary sandstone and calcareous mudstone on the coast 40-50 km northwest of the epicentre (Figure 2). The Little Wanganui Head (210 million $\mathrm{m}^{3}$ ) and Whitecliffs (120 million $\mathrm{m}^{3}$ ) landslides were probably triggered by at least MM9 shaking. Another significant 1929 rock fall site on an old coastal cliff near the Little Wanganui River mouth has recently been the subject of a resource management dispute.

The Murchison earthquake also triggered numerous very large rock slides and avalanches of Palaeozoic granites, volcanics, and conglomerates in the ranges of northwest Nelson, many forming landslide-dammed lakes in narrow mountain valleys. Several very large rock avalanches ranging in size from $\sim 2$ to 18 million $\mathrm{m}^{3}$ occurred on high mountain ridges of the Tasman Mountains, at the northern limit of the landslide-affected area $70-90 \mathrm{~km}$ north of Murchison. Most of these formed landslide-dams that still remain intact, as illustrated by Figure 8 .

\section{$2.4 \quad$ Landslide dammed lakes}

Landslides triggered by the Murchison earthquake dammed many streams and rivers in the hill country and mountains of northwest Nelson. At least 38 significant landslide-dams were formed, of which 17 have breached or the lakes infilled, and 21 are still intact (Table 2). Landslide dams that still exist are mainly those formed by very large rock and debris avalanches in narrow valleys of the Tasman Mountains, for example, Upper Stanley (3), Lower Stanley (17), Lower Lindsay (29), Elmer (20), and Ugly (33). Figure 8 shows the Upper Stanley landslide-dam and lake, formed by the largest of these landslides. Most of the rock avalanches formed on high mountain ridges where there was conceivably significant topographic amplification of the seismic shaking. However, the many very large landslides and numerous smaller failures in the Tasman Mountains, almost $100 \mathrm{~km}$ north of the epicentre, suggests that the entire area was very strongly shaken, probably to at least intensity MM9 (Figure 2). The combined effects of steep terrain and very strong and prolonged earthquake shaking provided favourable conditions and opportunity for the formation of landsidedams. 


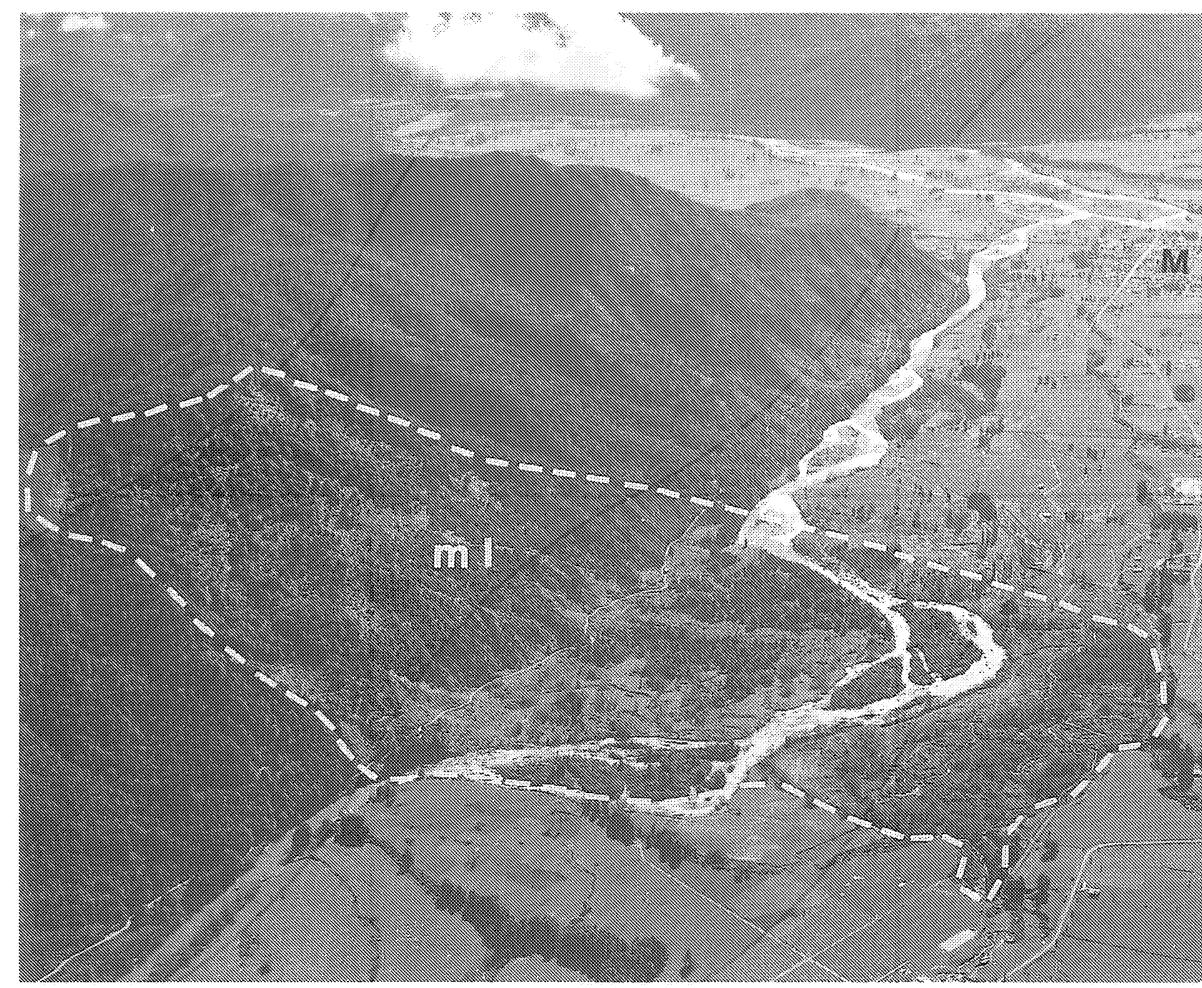

Frgure 3. Aerial view of the Matakitaki Landshide (ml, Shide HA, Table 2) triggered by the Murchison earhquake, which appears today as an area of brown vegetation and bush regrowh. Debris from this very large (18 million m. dip-slope rock slide travelled $\sim 1$ kn across the valley floor, killing 4 people in its path, and forming a landslide dam. The lake extended almost $5 \mathrm{~km}$ up valley, and lasted for almost ten years before the dam was washed out during a flood in the late $1930 \mathrm{~s}$ with no significant damage downstream. The town of Murchison (M) $5 \mathrm{~km}$ down valley was not affected by the landstide or breaching of the landslide dam.

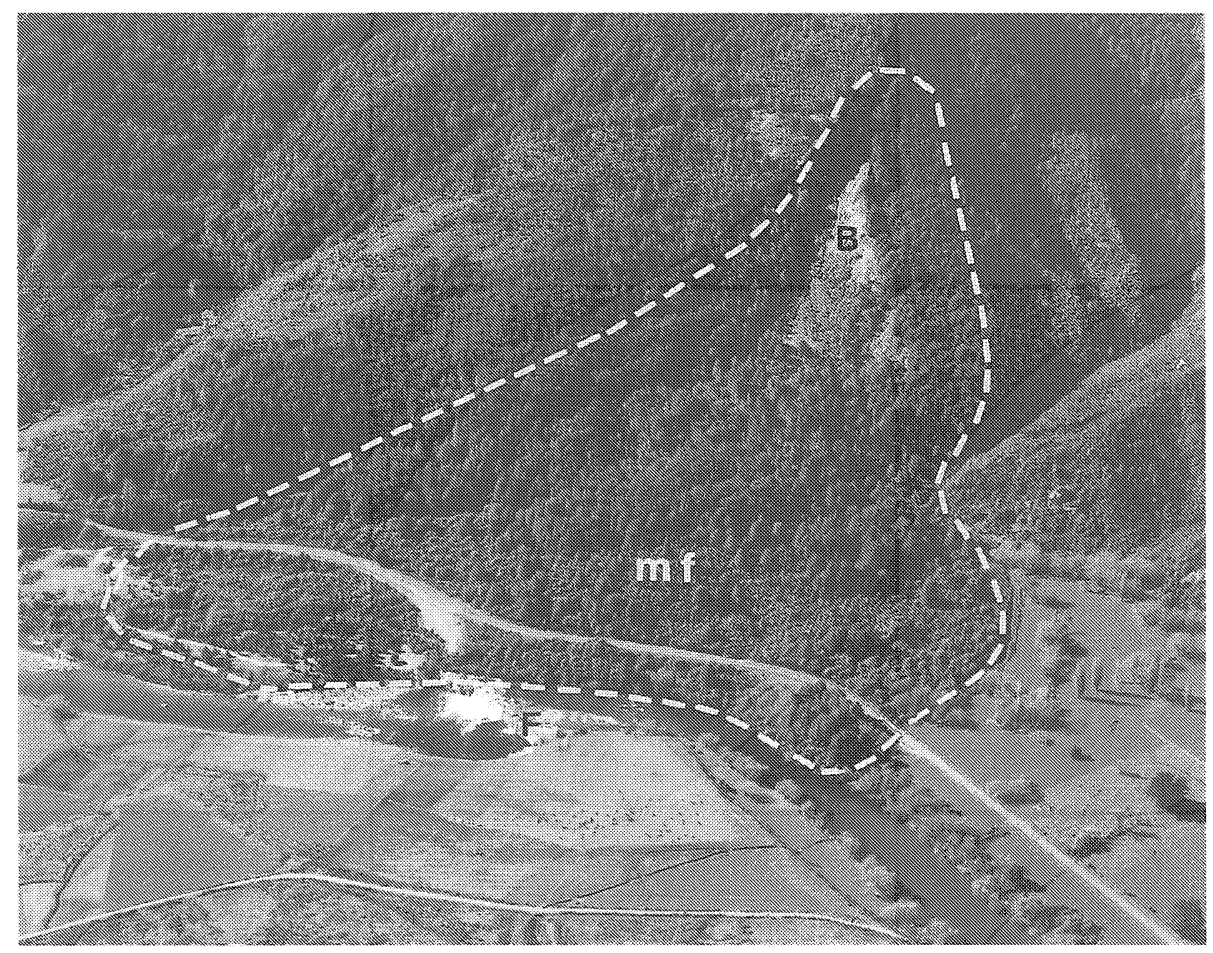

Figure 4. The Marwia Falls Landslide (mf, Slide "16, Table 2) killed 4 people when sandstone failed on west dipping bedding planes $(B)$ during the Murchison earthquake, burying a farmhouse under about 4.5 million $n^{3}$ of rock debris. The landside formed a landsidendammed lake that lasted for several days. Maruia Falls (F) was formed shorly after the earthquake, when the Maruia River was diverted from its course by landslide debris and exhumed an old riverbank formed by a band of hard sandstone. 


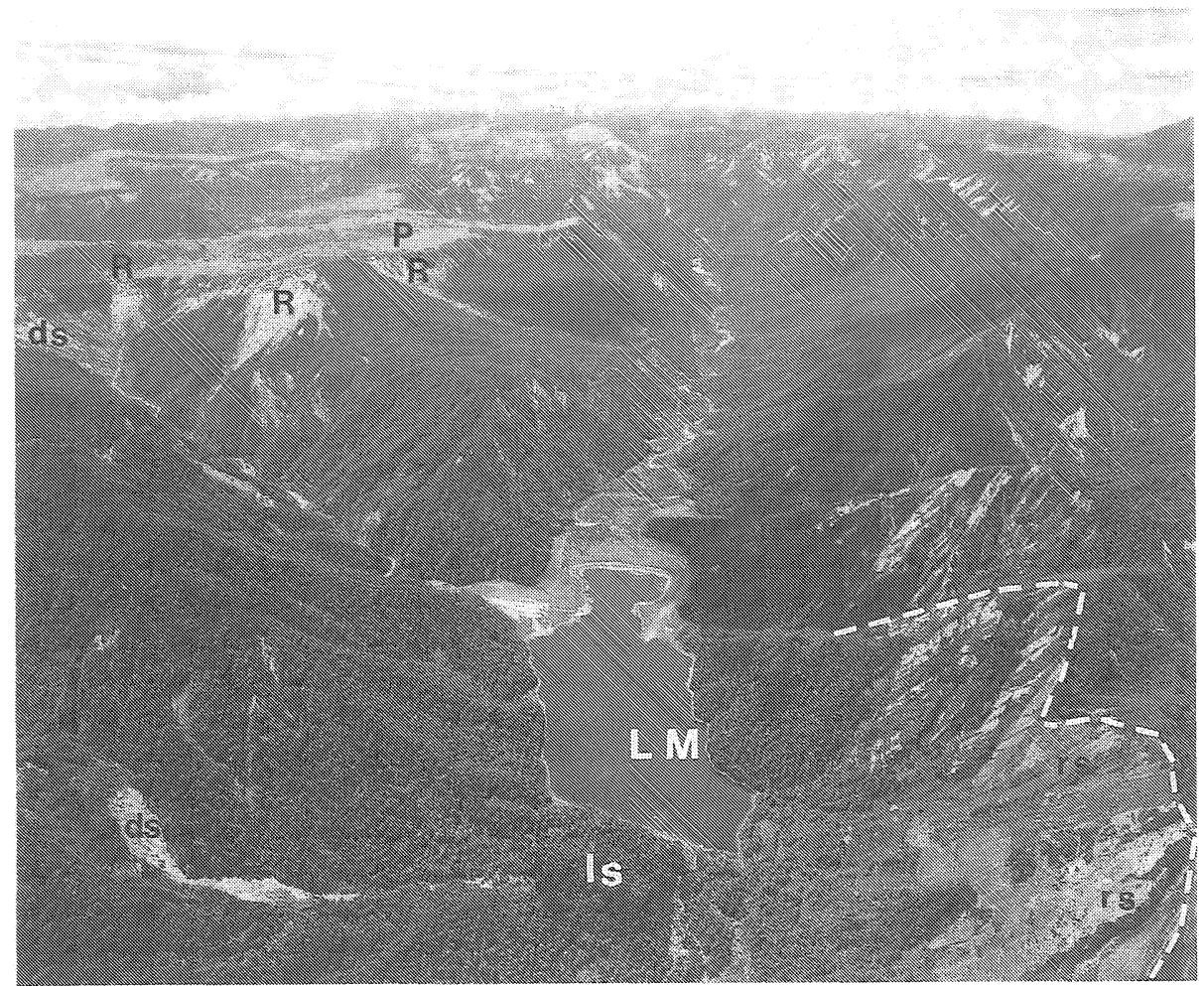

Figure 5. Aerial view of the Matiri Valley $15 \mathrm{~km}$ north of Murchison, which was very extensively damaged by landsides during the 1929 earhquake. The numerous scars of rock falls $(\mathbb{R})$ and debris slides (ds) are still clearly visible today, especially in the upper valley and along the steep scarps of Tertiary limestone and calcareotus mudstone bordering the 'Thowsand Acres Plateaw' (P). The old Zandslide (ls) damming Lake Matim (LM) was reactivated by the earthquake with afew small rock sides (rs) in the head scarp area.

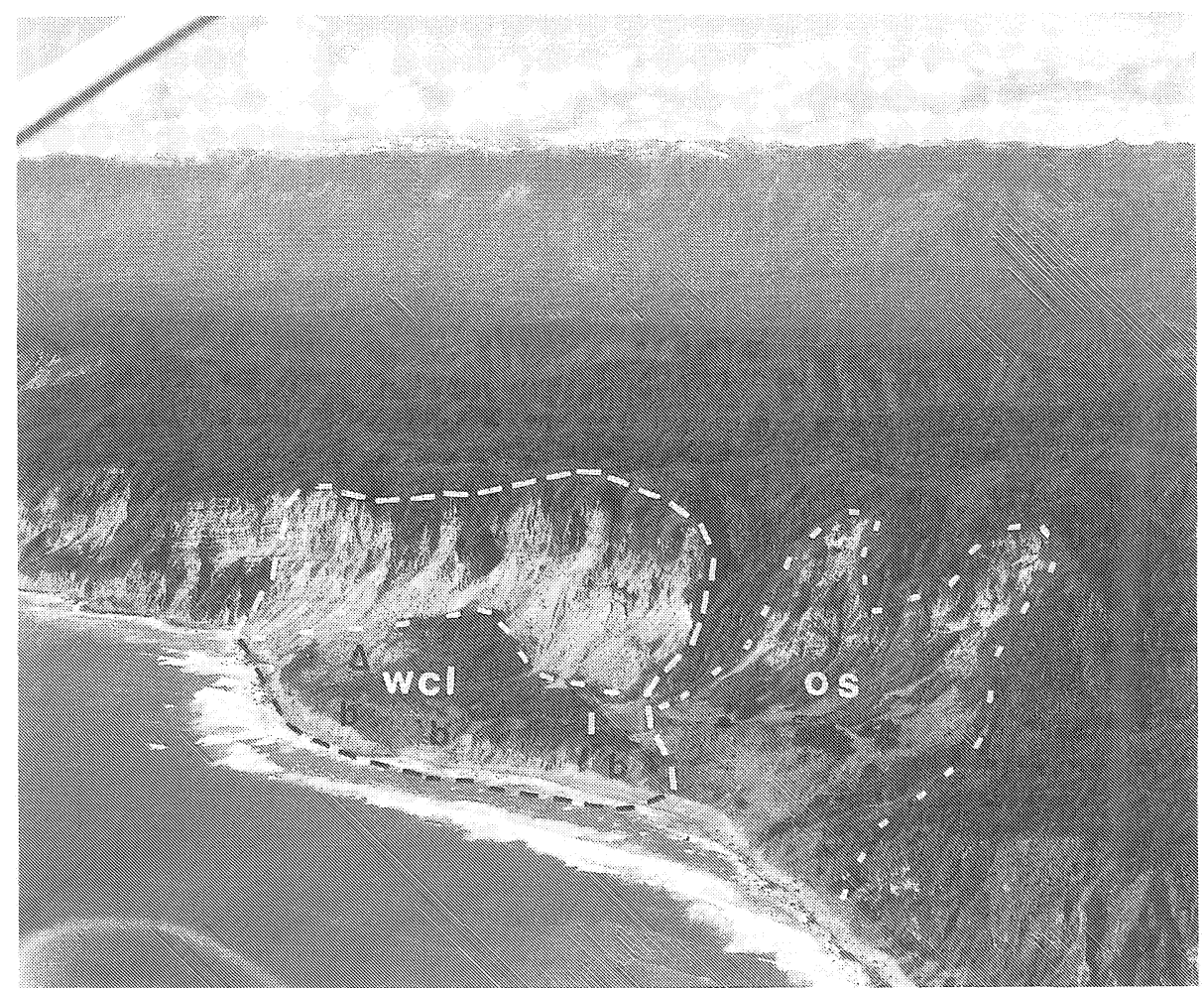

Figure 6. Whiteclifs Landside (wcl, Side $\# 2$, Table 2, viewed looking $\mathrm{NE}$ ), an extremely large landslide on the steep, $200-300 \mathrm{~m}$ high coastal cliffs nonth of Seddonville ( $39 \mathrm{knn}$ northwest of the epicentre). In this case, the beach (b) was uplifted $\sim 30 \mathrm{~m}$ and a small lake (l) formed on the toe of his extremely large (120 millon n') $^{3}$ rotational side in calcareous mudstone. The landslide mass is $\sim 500 \mathrm{~m}$ wide and extends about $1.5 \mathrm{knn}$ along the coast. At the southern end of the slide, small rock slides also occurred on cliffs above a large older landslide (os). Such extreme ground damage is consistent with at least MMP shaking in this area. 


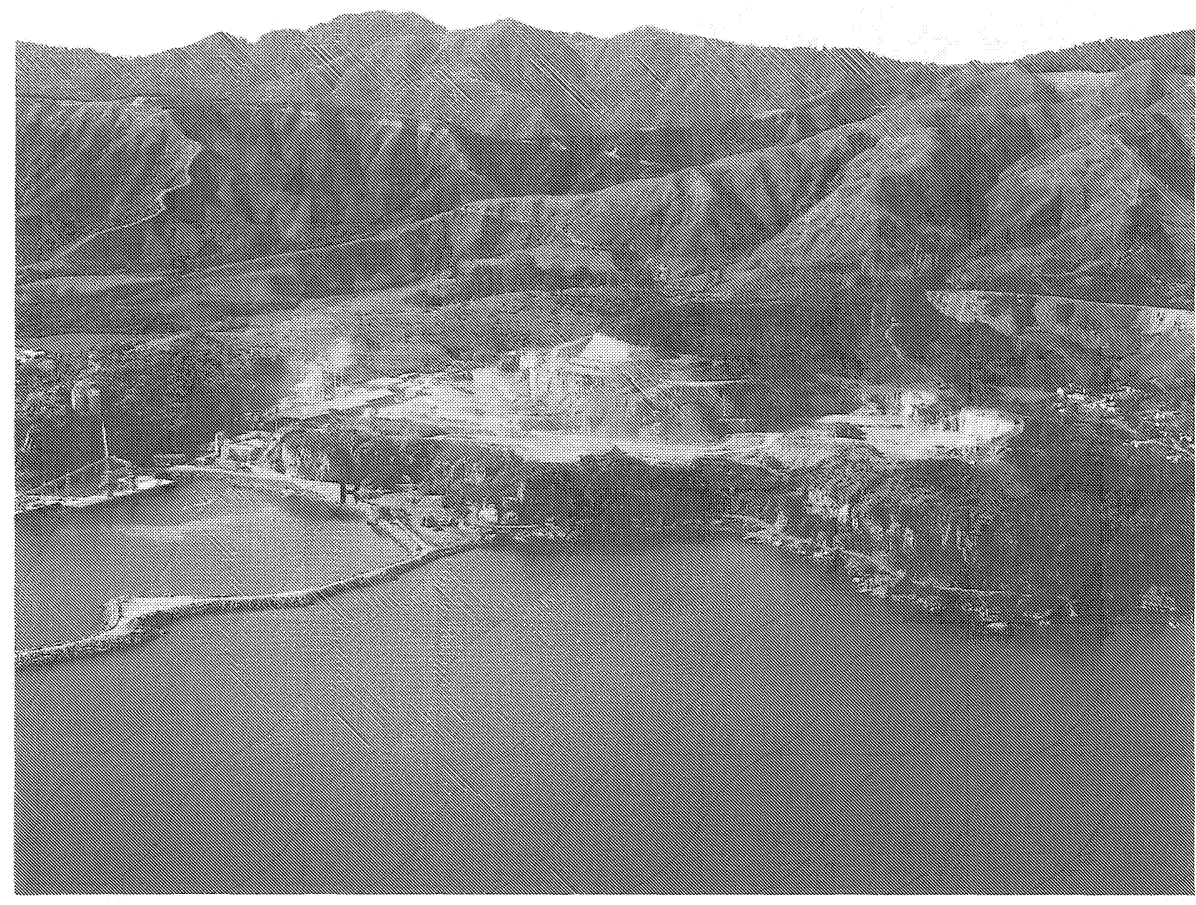

Figure 7. The Murchison earhquake triggered a fall of 'several great blocks' of Tertiary linestone on coastal cliffs at the Tarakohe Coment works -120 kn north of the epicentre (Slude 363 , Table 2). The rock fall (R) buried the powerhouse at the cliff base, killing an engineer. This was the most distant significant landslide that occurred, and is consistent wh MMO shaking.

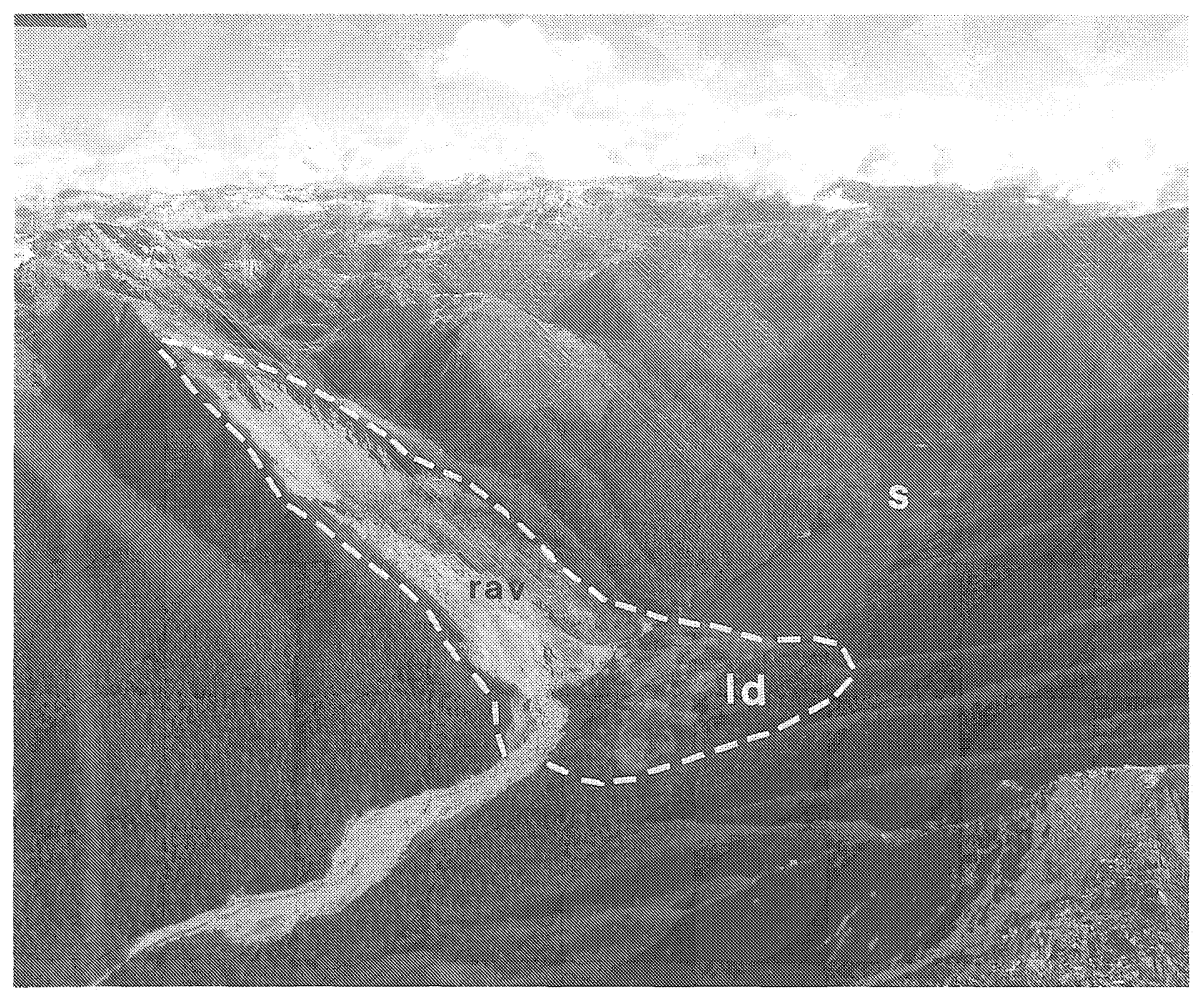

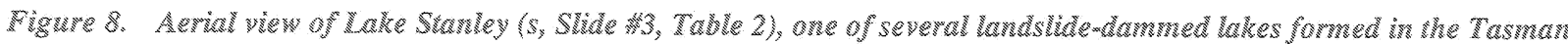
Mountains by landshides from high ridges during the Murchison earhwukk. Located 90 kn norh of the epicentre, wis very large (18 million m $^{3}$ ) rock avalanche (rav) in Palatozoic conglomerate and volcanics formed a landslide dam (Id) and lake (2.2 km long) that still exists loday. The landslide is $\rightarrow 2 \mathrm{~km}$ long, wilh a verical fall of $800 \mathrm{~m}$. Alhough topographic amplification of selsmic shaking was probably a factor in such ridge fallures, the many large landslides present shows that the entire area was very strongly shaken. Intensidy MMP was assigned in the area on the basis of these very large landsides. 
Large landslides also dammed temporarily many of the major rivers in the region, but these were mainly short-lived features that lasted only a few days, although some dams lasted for several weeks before being breached during floods, or the lakes infilled with sediment. Large rivers that were dammed for a few days or weeks include the Buller $(40,59)$, Maruia $(16,50)$, Little Wanganui (66), and Mokihinui (13), some of which have already been discussed. Short-lived debris dams also formed in several places along the Karamea River, remnants of which now form bouldery rapids, upstream of which are low-gradient ponded areas (for example, Garribaldi, 37 and Luna, 23). The large rock slide that dammed the Mokihinui River to a depth of $23 \mathrm{~m}$ at the entrance to the gorge caused the formation of an $11-\mathrm{km}$ long lake (Lake Perrine, 13). Some three weeks after the earthquake part of the dam was washed out, lowering the lake by $8 \mathrm{~m}$ and causing a large flood that inundated Seddonville. Residents were forced to seek higher ground, and the hall and some houses were shifted off their foundations (Henderson, 1937). Rather surprisingly, the landslide-dam in the Matakitaki River (4) lasted for almost 10 years, but it too was eventually washed out during a flood, fortunately with few effects downstream.

Most of the landslide-dams formed in narrow mountain valleys tended to survive because the dam volume is generally much greater than the lake volume, and is beyond the erosive power of small streams to remove. For example, the volume of the Stanley landslide $\left(\sim 18 \mathrm{mil} \mathrm{m}^{3}\right)$ is about twice the lake volume $\left(\sim 10 \mathrm{mil} \mathrm{m}^{3}\right)$, hence the overtopping and erosion potential of the upper Stanley River, which has a relatively small catchment, is relatively low even during a large flood. From a dam-break hazard perspective, the chances of the Stanley landslide-dam, or any other remaining 1929 landslide-dam breaching after more than 70 years are probably very low. Most of the dams that were susceptible to failure did so days, months, or a few years after formation. However, further research and dam-break modelling is needed to examine in more detail the reasons why some dams failed and others survived, determine thresholds for landslide-dam failure versus survival (dam and lake size, overtopping erosion potential etc.), and develop a better understanding of future dam-break hazards in areas affected by a large earthquake.

\subsection{Liquefaction effects}

The very strong and long-duration shaking associated with the 1929 earthquake also caused widespread soil liquefaction effects in alluvial deposits, although the earlier reports did not identify liquefaction as the process. This caused some researchers (Fairless and Berrill, 1984) to overlook the evidence for liquefaction and express surprise at its absence. However, Henderson (1937) had clearly observed widespread lateral spreading, reporting that fissuring and sand ejection was common along riverbanks in the Murchison area, and also along the waterfronts at Westport and Greymouth, causing damage to wharves and adjacent land.

An eyewitness account (Murchison District Historical and Museum Society, 1999) in the upper Matakitaki valley refers to: "... slips occurring on the hills in every direction, ... cracks appearing in the paddock, and these opened and closed, water from underground spurted into the air. After a while of this the paddock looked as if there had been a flood...".
Other cases of liquefaction during the Murchison earthquake have since been reported (Berrill, et al., 1988). Sand boils with little associated damage are reported to have occurred in Westport, Greymouth, Seddonville, Little Wanganui, Karamea, and also $80-90 \mathrm{~km}$ to the north at Takaka and Riwaka (Figure 2).

\subsection{Relationship of landsliding to MM intensity and earthquake source}

Observations by geologists and reports in newspapers show that the largest and most numerous landslides occurred in the mountains from the Buller River about $60 \mathrm{~km}$ north to the Karamea River, and for about $16 \mathrm{~km}$ to the south of the Buller (Henderson, 1937). However, recent mapping (Figure 2) has shown that the landsliding was more widespread than previously recognised. Numerous small regolith slides and rock falls and many very large landslides occurred in an almost continuous zone extending some $80-90 \mathrm{~km}$ north of where the White Creek Fault crosses the Buller River. Isolated slope failures also occurred $55 \mathrm{~km}$ to the east near Lake Rotoiti, and at Greymouth $110 \mathrm{~km}$ to the southwest, reflecting the presence of locally steep slopes or other adverse site conditions. In general, the steeper slopes (sharp ridges, spurs, and edges of gravel terraces) were more affected than gentle slopes, but several large catastrophic slides also occurred on moderate dip slopes.

The isoseismals shown in Figure 2 are based on Dowrick (1994) but have been modified by results of the 1997 study (as it progressed) and also overseas studies (e.g., Keefer. $1984 \mathrm{a})$. These have shown that within $\sim 40-50 \mathrm{~km}$ of the nominal epicentre in the Buller Gorge, the landslide damage is consistent with MM9 and MM10 earthquake shaking. Accordingly, the many large landslides formed during the earthquake have been used to define a zone of MM10 intensity, which extends a considerable distance north of the epicentre (Figure 2). Similarly, the existence of a group of large landslides up to $90 \mathrm{~km}$ to the north of the Buller River suggest that the MM9 isoseismal extended $40 \mathrm{~km}$ further north than previously determined. Few landslides were reported in the MM7 and MM8 areas, particularly to the south and southeast of the inferred epicentre.

The distribution of landslide damage indicates that the zone of very strong shaking extended from the White Creek fault rupture in the Buller Gorge northward through the mountains of northwest Nelson. The pattern of landsliding suggests that the MM10 zone extended for at least $\sim 65 \mathrm{~km}$ north of the Buller River, but only $\sim 10 \mathrm{~km}$ to the south. From studies currently in progress (D. Doser, GNS) the fault rupture associated with the 1929 earthquake is now estimated to be about $75 \mathrm{~km}$ long (D. Doser, pers. comm. to David Dowrick 2000). This is consistent with the length of the landslidebased MM10 zone in Figure 2. The main zone of aftershocks shown on this figure approximately matches the area of landslide damage, and supports a fault rupture length of around $70-80 \mathrm{~km}$. While the earthquake epicentre could have been at either end of the rupture, surface faulting at White Creek suggests it was probably at the south end (pers. comm. David Dowrick, 2001). 
However, there is clear evidence that the distribution of earthquake-induced landsliding is influenced more by the fault rupture zone than the epicentre. For instance, the largest and most numerous slips in the mountains from the middle Karamea River to the Buller River are located along the line of the inferred fault rupture (A-B in Figure 2). Other important observation that can be made is that most of the large landslides are located on the upthrown or hanging wall of the reverse fault rupture (Abrahamson and Somerville, 1996), where the shaking is about $50 \%$ stronger at short periods (0-0.06 s) than outside this area. Although this is most likely one reason for the severity of the landsliding, the steep terrain and susceptible geology (dip slopes, steep scarps, and thick colluvium) were also very important.

\section{RELATIONSHIPS OF LANDSLIDING TO SEISMIC PARAMETERS, SLOPE, GEOLOGY, AND OTHER ENVIRONMENTAL FACTORS}

Several measures were used in the 1997 study (Hancox et al., 1997) to relate earthquake-induced landslide distribution to seismic parameters and environmental factors. As shown by Keefer (1984 a), the 1997 study also demonstrated that earthquake magnitude, depth, and shaking intensity strongly influence landsliding during earthquakes. Environmental factors such as slope steepness and geology (rock and soil type and strength), groundwater, and the seismic setting were also found to be important in controlling the location and severity of earthquake-induced landslides. These relationships are summarised and discussed below.

\subsection{Earthquake magnitude and shaking intensity}

The 1997 study showed that the minimum magnitude $(\mathrm{M})$ for minor earthquake-induced slope failure in New Zealand is about M 4.6-M 5, although significant landsliding occurs only during shallow earthquakes of M 6 or greater, depending on their depth and location, and at minimum shaking intensities of MM6. Note that the earthquake database examined included isoseismal maps for $\mathrm{NZ}$ earthquakes as low as M 3.5 (Downes, 1995), and some smaller-magnitude events recorded in the NZ Earthquake Catalogue (for which no significant felt effects or landslide damage was reported). Figure 9 illustrates the relationship that was determined for earthquake-induced landsliding to earthquake magnitude and MM intensity in New Zealand.

\section{Landslides}

Historically, most of the widespread and damaging landsliding has been caused by shallow (depth less than 45 $\mathrm{km}$ ), longer-duration earthquakes of magnitude 6.2 to 8.2 , at intensities of MM7 to MM10, and at distances up to about $150 \mathrm{~km}$ from the epicentre. Landslides formed at intensity MM6 generally caused little damage. The minimum earthquake magnitude threshold for significant earthquakeinduced landsliding in New Zealand, for all rock types and types of slides, is therefore considered to be about M 6 .
Although peak ground acceleration is regarded as important in landslide initiation, the duration of strong shaking is probably more significant in producing very large landslides and higher felt intensities. The minimum MM intensity threshold for landsliding is generally MM6, but the most common intensity levels associated with landslides during earthquakes in N Z are MM7 and MM8 (Figure 9). Although landsliding is more widespread and damaging at intensities MM9 and MM10 (as it was during the 1929 Murchison and 1968 Inangahua earthquakes), very strong shaking at these levels has occurred less frequently. Most earthquake-induced landslides at all intensities were small $\left(<1000 \mathrm{~m}^{3}\right)$ disrupted slides or falls of rock and soil. Because landslide reporting tends to be incomplete in areas of lower intensity, especially for the older events, there could be a slight sampling bias towards higher intensity levels (MM8 and above). However, this is unlikely to significantly affect the EIL relationships and environmental response criteria that were determined.

The relationships between landsliding and seismic parameters determined for New Zealand are generally consistent with, but slightly higher than those of Keefer (1984 a), based on a study of worldwide and United States earthquakes. Keefer found that the threshold earthquake magnitude for landsliding was M 4 (compared to M 5 in NZ), and the minimum threshold intensity for landsliding was MM4 to MM5 (MM6 in NZ), although the predominant minimum intensities were MM6 and MM7 (MM7 and 8 in NZ). The reasons for these relatively minor differences are uncertain, but they probably relate to a combination of climatic, geological, and topographic factors (overseas EIL data are from both arid and humid, tropical areas, often in steep mountainous terrain).

\section{Liquefaction}

During New Zealand earthquakes, the minimum intensity threshold for soil liquefaction was commonly MM7 for sand boils (sand and water ejections), and MM8 for lateral spreading in alluvium (ground fissuring, often accompanied by sand and water ejection). However, such effects may also occur at one intensity level lower in areas of highly susceptible materials or high groundwater levels, as shown by the Edgecumbe 1987, and Ormond 1993 earthquakes.

Liquefaction-induced ground failure (mainly lateral spreading fissures and settlements) is most common at intensities MM8 to MM10 and distances of $10-100 \mathrm{~km}$.

The minimum magnitude for liquefaction appears to be about M 6, and is most likely to occur during longer-duration moderate and large earthquakes. However, sand boils have been reported overseas in earthquakes as low as M5 in highly susceptible materials. The general agreement between the New Zealand and Japanese liquefaction data and about $90 \%$ of Keefer's (1984 a) data for lateral spreads and flows, suggests that the maximum distances of liquefaction from the epicentre in New Zealand may be predicted by the formula of Kuribayashi and Tatsuoka (1975), as follows:

$$
\log _{10} R_{\max }(\text { distance, } k m)=0.77 \mathrm{M}(\text { magnitude })-3.6 \text {. }
$$




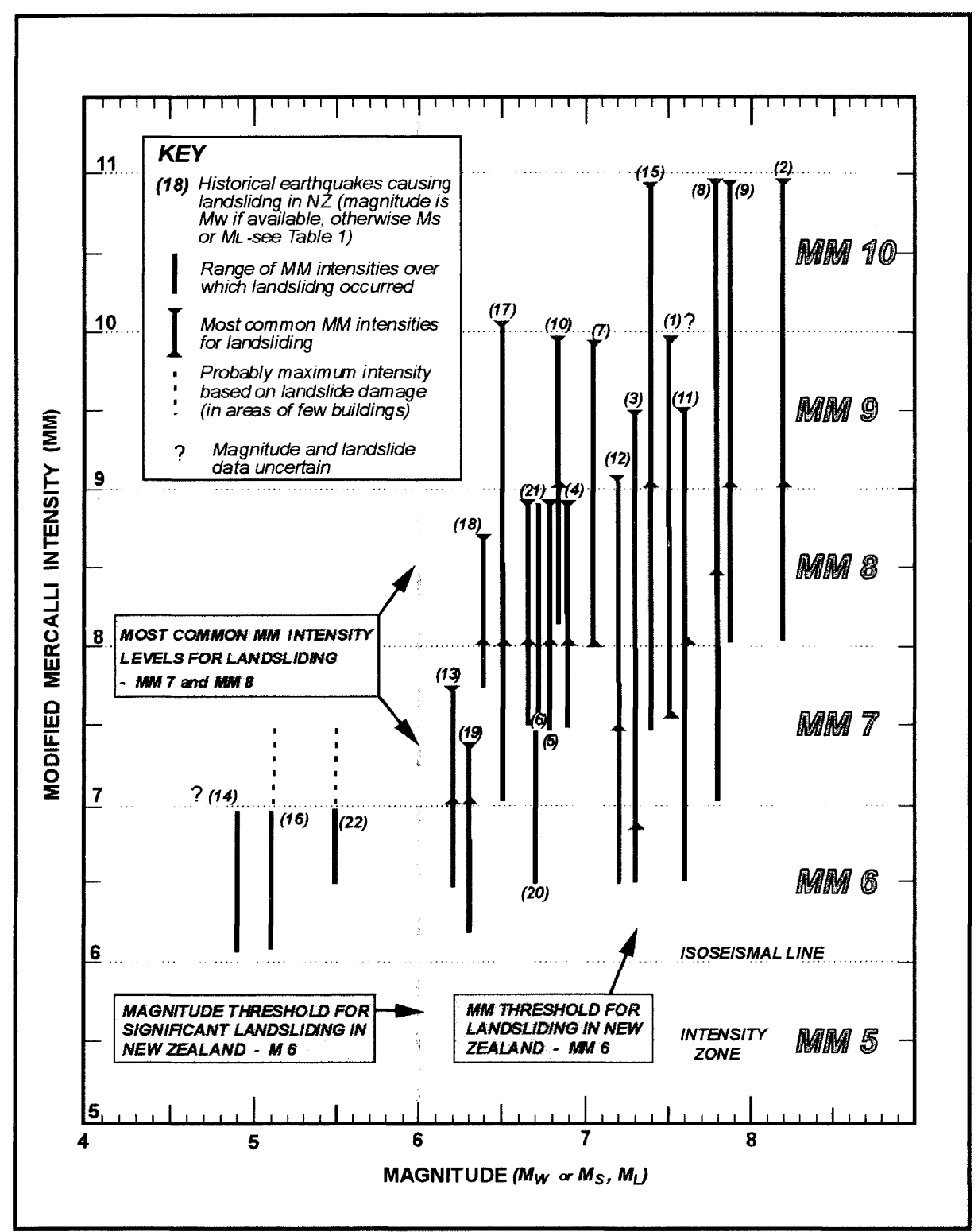

Figure 9. Relationship of earthquake magnitude and the range of MM intensity at which landsliding occurred during historical earthquakes in New Zealand. The triangles and bars show the most common range of MM intensities at which landsliding occurred for the earthquakes listed in Table 1. 


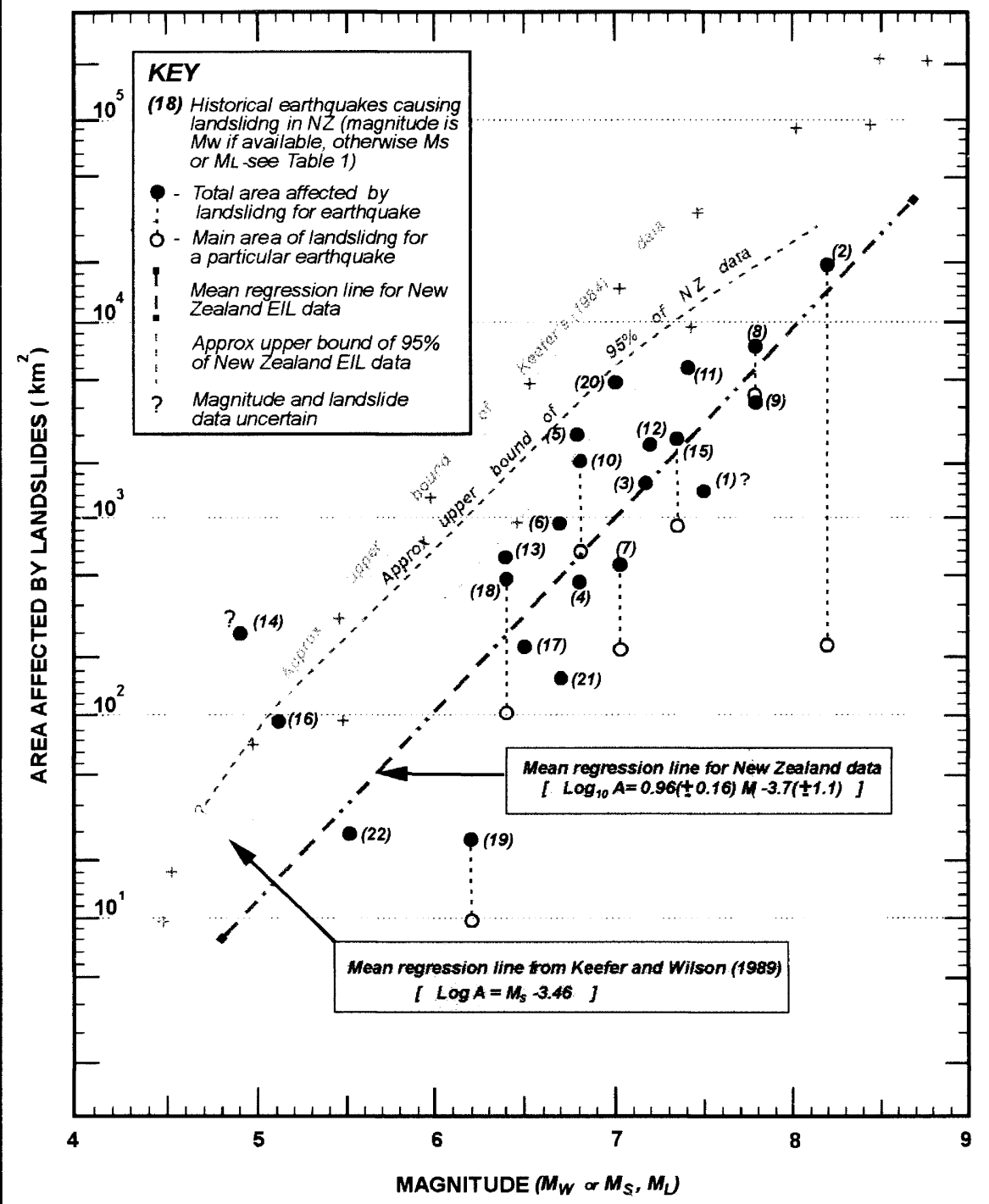

Figure 10. Relationship of the area affected by landslides during historical earthquakes of different magnitude in New Zealand. The large dots (๑) show the total area affected by landsliding, while circles (O) show the main areas affected during the earthquakes listed in Table 1. 


\subsection{Area affected by landsliding}

The relationship of earthquake magnitude and the area affected by landsliding in New Zealand during historical earthquakes is shown in Figure 10 . This shows that the maximum areas likely to be affected by landslides (in reality the area in which landslides occur) are: $100 \mathrm{~km}^{2}$ at $\mathrm{M} \mathrm{5,500}$ $\mathrm{km}^{2}$ at $\mathrm{M} \mathrm{6}, 2000-3000 \mathrm{~km}^{2}$ at $\mathrm{M} \mathrm{7,} 7000 \mathrm{~km}^{2}$ at $\mathrm{M} \mathrm{7.8}$, and up to $20,000 \mathrm{~km}^{2}$ at $\mathrm{M} 8.2$. Earthquakes causing the most extensive landsliding in New Zealand were: 1855 Wairarapa (M 8.2, 20,000 km $)$; 1929 Murchison $\left(\mathrm{M}_{\mathrm{s}} 7.8,7000 \mathrm{~km}^{2}\right.$ ); 1934 Pahiatua (Ms7.6, $6500 \mathrm{~km}^{2}$ ); 1931 Hawke's Bay $\left(\mathrm{M}_{\mathrm{s}} 7.8,4700 \mathrm{~km}^{2}\right)$; and the 1968 Inangahua $\left(\mathrm{M}_{\mathrm{s}} 7.4,3200\right.$ $\mathrm{km}^{2}$ ).

The following expression was developed to predict the average area likely to be affected by landslides during earthquakes in New Zealand:

$\log _{10} A\left(\right.$ area $\left.\mathrm{km}^{2}\right)=0.96 \mathrm{M}($ magnitude $)-3.7$.

Conversely, earthquake magnitude can be estimated from the area affected by landsliding using the expression:

$M=1.04 \log _{10} A+3.85$.

These relationships differ slightly from those for overseas earthquakes (Keefer, 1984 a), which generally affect larger areas, probably because of topographic and climatic differences.

\subsection{Size and distance of landslides from epicentre}

The size of landslides and distances from the epicentre at which they occur in New Zealand are clearly related to magnitude and intensity, as follows:

- Very small to small landslides $\left(\leq 10^{3}-10^{4} \mathrm{~m}^{3}\right)$ occur at maximum epicentral distances of: $10 \mathrm{~km}$ for M 5 (MM6); $30 \mathrm{~km}$ for M 6 (MM7); $100 \mathrm{~km}$ for M 7 (MM7); and almost $300 \mathrm{~km}$ for M 8.2 (at MM6). The threshold for $10^{4} \mathrm{~m}^{3}$ slides is magnitude $\sim \mathrm{M} 6$.

- Moderate to large landslides $\left(10^{4}-10^{6} \mathrm{~m}^{3}\right)$ generally only occur at $\sim \mathrm{M} 6.3-6.5$ or greater at epicentral distances of about $5 \mathrm{~km}$ (MM8) to $70 \mathrm{~km}$ (MM7).

- Very large and extremely large landslides $\left(1-5010^{6} \mathrm{~m}^{3}\right.$, and $>50 \times 10^{6} \mathrm{~m}^{3}$ ) occur only at magnitudes greater than $\sim \mathrm{M} 6.5$ and 7.0 respectively, at epicentral distances of up $100 \mathrm{~km}$ or more (MM 8-10). The threshold for $10^{8} \mathrm{~m}^{3}$ slides appears to be $\sim$ M7.5 (MM9 or greater).

In mountainous areas where there are few buildings, the occurrence of extensive and very large landslides was used in the 1997 study (as it progressed) to redefine MM9 and MM10 zones for the 1929 Murchison and 1855 Wairarapa earthquakes, and also to establish a MM9 zone for the 1929 Arthur's Pass earthquake. The size and numbers of landslides within different intensity zones are magnitude and distance-dependant. As might be expected, smaller landslides occur at lower intensities, and at a greater range of magnitudes and distances, reflecting both variations in the factors causing landsliding, and also the scatter (uncertainty) in the accuracy of intensity data and earthquake locations.

As with the area affected by landsliding, the distance from the epicentre at which landslides occur varies considerably with magnitude, ranging from less than $1 \mathrm{~km}$ to $100-200 \mathrm{~km}$ for magnitudes of M 7.5 to $M 8.2$. In general, the maximum distances to landslides during New Zealand earthquakes are usually less than those associated with overseas earthquakes. This difference is probably due to a combination of topographic, geologic, climatic, and seismic factors discussed previously, but the relative importance and interactions of these factors are currently unknown.

\subsection{Fault rupture zone and aftershocks}

The 1997 study showed that there is seldom a clear correlation of landslide distribution with ground surface faulting, possibly because much of the faulting was of limited extent, or of a secondary nature. However, a good correlation was demonstrated between landsliding and the fault rupture zone indicated by aftershocks, as shown by the 1929 Murchison, 1968 Inangahua, 1990 Weber, and 1994 Arthur's Pass earthquakes. This association suggests that landslide distribution can provide a general indication of the epicentre location and extent of the fault rupture zone of an earthquake.

However, allowance must also be made for topographic features such as cliffs and escarpments, which are more susceptible to failure during earthquakes. The 1997 study was unable to show a definite link between landslide distributions, the earthquake focal plane mechanism, and focusing of seismic shaking. However, seismic focusing may have occurred during some events, for example, 1929 Murchison and 1932 Wairoa. Further detailed studies of these earthquakes may provide definite evidence of such an effect and a better understanding of landslide damage likely during future earthquakes.

\subsection{Topography}

The recent studies have shown that the occurrence of landslides during earthquakes is strongly influenced by the topography; especially slope angle and slope aspect in relation to geology (Figure 11). Earthquake-triggered slope failures occur mostly on slopes of $20^{\circ}$ or greater, with the most common failures being rock and soil falls on cliffs, steep escarpments, gorges, and gravel banks, and high unsupported man-made cuts. Such features are highly hazardous, being more susceptible to rapid failure because of rock defects, low strength, and topographic amplification of shaking.

Figure 11 is a plot of the 140 largest landslides formed on natural slopes during six important historical $\mathrm{N} \mathrm{Z}$ earthquakes (Wairarapa 1855, Arthur's Pass 1929, Murchison 1929, Napier 1931, Inangahua 1968, and Arthur's Pass 1994). Landslides in different rock types and are plotted in relation to slope angle and landslide direction relative to the epicentre. The more numerous smaller landslides $(<1,000-$ $10,000 \mathrm{~m} 3$ ) that affected road and rail cuts, gravel banks and terrace edges during earthquakes are not shown, but most would typically plot at slope angles greater than $50^{\circ}$.

No general association could be established between landslide direction and the earthquake epicentre, although possibly 4 times the number of large landslides were formed on slopes facing directly or obliquely away from the epicentre than towards it. This may be a 'directivity' effect caused by stronger propagation of seismic waves away from the epicentre or along the fault rupture zone, possibly causing material to be 'thrown off' slopes in some locations (e.g., Murchison 1929). 
However, it is generally clear that topographic features controlled by geology (scarps, dip slopes, ridge and valley alignment) generally have a strong influence on slope failure direction. Dip slopes are those where bedding dips down slope into a valley, and scarp slopes occur where bedding dips into the slope. Dip slopes are more susceptible to bedding plane slides, whereas scarp slopes are prone to rock falls and avalanches because of their precipitous nature, rock mass defects, and weathering of exposed rock faces.

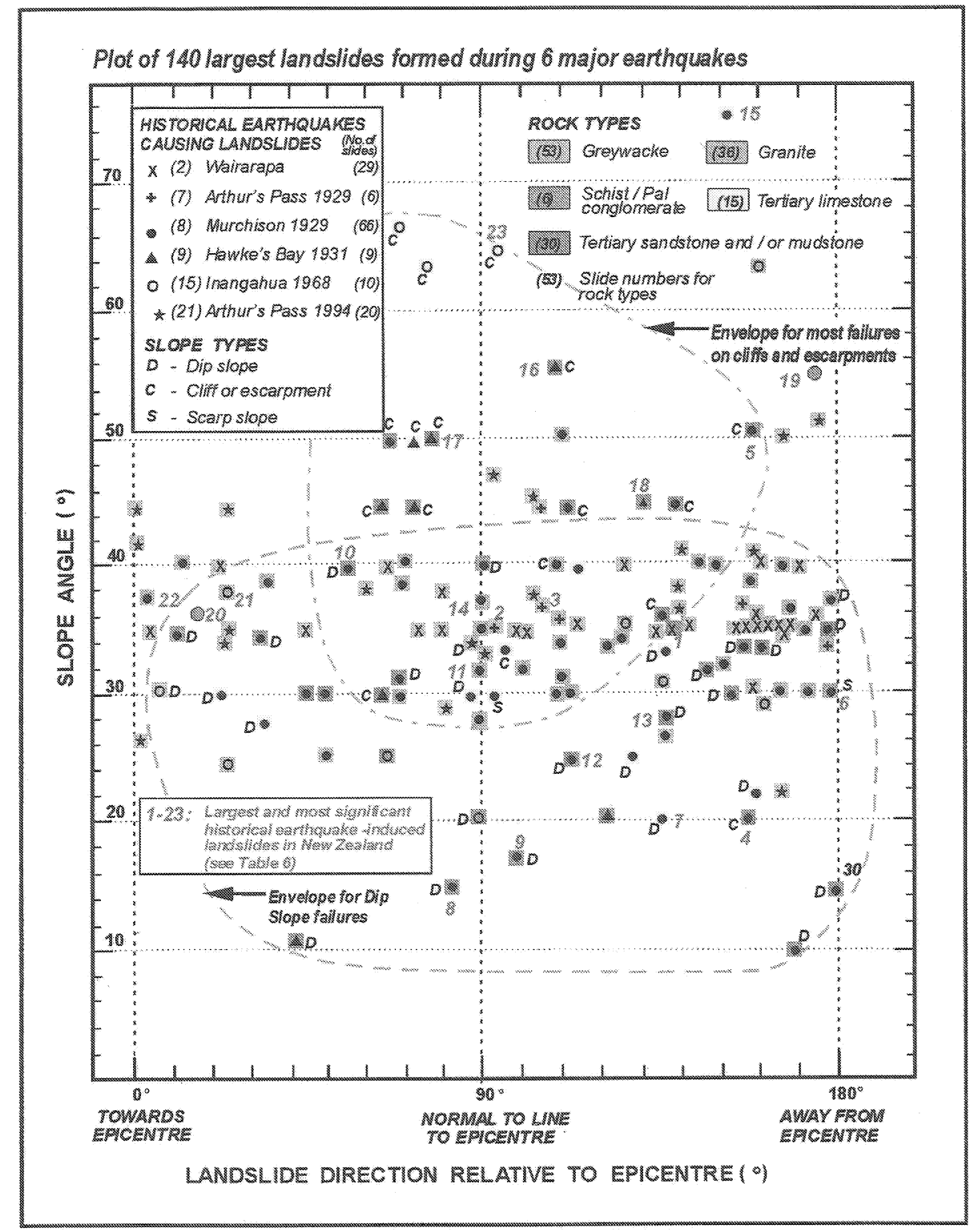

Figure 11. Relationship of earthquake induced landslides on natural slopes in New Zealand in relation to slope angle, rock type, slope type, and direction of fallure relative to the epicentre for six inportant earthouakes (as listed). No general association can be shown between landslide direction and the epicentre, except that nore large landslides fall directly or obliquely away from the epicentre than towards it. However, topographic features controlled by geology (scarps, dip slopes, ridge and valley alignment) clearly influence failure direction. Slope angle exents strongest control on Landsliding. The largest and most significant landslides (numbers 1.23 , and Table 6) occurred on slopes ranging from $15.75^{\circ}$, allhough $\sim 75 \%$ of these formed on slopes steeper than $\sim 30^{\circ}$. Failures on flatter land were generally dip-slope slides controlled by geology. The more numerous smaller landslides $\left(<1,000 \cdot 10,000 \mathrm{~m}^{3}\right)$ on gravel banks, lerrace edges, and road cuts during earhinukes are not shown, but they generally affected slopes steeper than $50^{\circ}$ and more than $2.3 \mathrm{~m}$ high in strongly shaken areas $(\geq M M 8)$. 
Dip slope slides in Tertiary sandstone and mudstone often occur on gentle to moderately steep slopes $\left(10-35^{\circ}\right)$, as illustrated by the Matakitaki Landslide discussed earlier. Such failures are potentially very dangerous because the slopes on which they occur on do not appear hazardous. In wide valleys debris runout from dip slope slides can extend a kilometre or more across the valley floor, and overwhelm houses or other structures that may be considered safe (see Figures 3, 4, and 11). Very large rock avalanches are caused by earthquakes of $\mathrm{M} 6.5$ or greater on slopes steeper than 25 $30^{\circ}$, and more than $100-200 \mathrm{~m}$ high, especially on strongly shaken high narrow ridges and scarps such as those in NW Nelson. These findings are consistent with those of Keefer (1984 b).

Areas below steep natural and man-made slopes are therefore seen as very hazardous during earthquakes. Steep narrow mountain valleys are particularly prone to large rock avalanches during earthquakes, and often they result in the formation of landslide dams (Figure 8). In New Zealand, some buildings have been destroyed and at least fifteen people killed by earthquake-triggered slides and falls from steep slopes, cliffs, and unsupported man-made cuts. As already discussed, flooding caused by the breaching of landslide dams creates an additional hazard in areas downstream.

The occurrence and size of landslides during earthquakes is most strongly influenced by slope angle (combined with slope height) and slope type (Tables 4 and 5). The largest and most significant earthquake-triggered failures occur on natural slopes steeper than $35^{\circ}$, particularly cliffs and escarpments, and some high road cuts and other open excavations (Table 6). About $60 \%$ of failures are on slopes of steeper than $35^{\circ}\left(20 \%\right.$ on slopes steeper than $45^{\circ}$ ), while only $10 \%$ of failures were on slopes of $11-25^{\circ}$. This reflects the fact that there are relatively fewer natural slopes steeper than $45-50^{\circ}$, and these very steep slopes are often formed of stronger bedrock and may be less prone to failure. However, the more numerous smaller failures that occur on cliffs, gravel banks and terrace edges, and very steep man-made cuts for roads, railway lines, and excavations are not represented in these figures. If they had been, the numbers of landslides plotted on slopes steeper than $45-50^{\circ}$ (Figure 11) would have been very much higher.

Very large landslides formed on gentle to moderate slopes (10-20 $)$ are mainly dip-slope failures in Tertiary sedimentary rocks. Large rock slides and rock fall avalanches are more likely to be triggered by longer-duration shaking associated with earthquakes greater than M 7, on slopes steeper than 25$30^{\circ}$ and more than $100-200 \mathrm{~m}$ high (Tables 5 and 6 ). Note that the slope angles and relative abundances shown in Table 5 are similar to those determined by Keefer (1984 a). In susceptible steep terrain, topographic amplification of shaking may occur during earthquakes. This occasionally results in very large rock avalanches, cracking and 'ridge rents' on high ridges, and more commonly in large rock falls from high cliffs, escarpments, and some man-made cuts. Isolated failures of this type may be regarded as local site effects, but numerous failures indicate general strong shaking of at least intensity MM8 to MM9. This is consistent with relationships for landsliding during overseas earthquakes (Keefer, 1984 a).

Table 4. Natural slopes and rock types affected by earthquake-induced landslides

\begin{tabular}{|c|c|l|}
\hline Slope Range & $\begin{array}{l}\text { Approx \% EIL } \\
\text { Slope failures }\end{array}$ & \multicolumn{1}{c|}{ Typical slope and rock types } \\
\hline $0-10^{\circ}$ & $<1 \%$ & Few failures, several low-angle (c10 ) dip slope slides in Tertiary mudstone \\
\hline $11-25^{\circ}$ & $10 \%$ & Mainly dip slope slides in interbedded Tertiary sandstone and mudstone, and limestone \\
\hline $26-35^{\circ}$ & $30 \%$ & $\begin{array}{l}\text { Dip slope failures in bedded Tertiary rocks (as above); steeper slopes in hard rocks } \\
\text { (greywacke, schist, granites etc). }\end{array}$ \\
\hline $36-45^{\circ}$ & $40 \%$ & $\begin{array}{l}\text { Steep cliffs, escarpments, and gorges in Tertiary limestone; scarp slopes in hard rocks } \\
\text { (greywacke, schist, granites etc). }\end{array}$ \\
\hline$>45^{\circ}$ & $20 \%$ & $\begin{array}{l}\text { Steep cliffs, scarps, gorges in Tertiary sediments, greywacke, schist, granites etc, } \\
\text { especially in steep glaciated and alpine areas. } \\
\text { (Note: Numerous smaller failures on gravel banks, terrace edges, road, railway, and other } \\
\text { cuttings not represented in these \% values or Figure 11). }\end{array}$ \\
\hline
\end{tabular}


Table 5. Typical slope threshold levels for main types of earthquake-induced landslides

\begin{tabular}{|c|c|}
\hline Landslide Type & Occurrence characteristics \\
\hline Rock and debris falls & Very common, very small to large. Minimum slope angle $40^{\circ}$ \\
\hline Rock and debris slides & $\begin{array}{l}\text { Very common, very small to large. Minimum slope angle } 25-35^{\circ} \text {. } \\
\text { Less common on slopes of } 20^{\circ} \text { or less }\end{array}$ \\
\hline Rock and debris avalanches & $\begin{array}{l}\text { Very common, moderate to very large. Minimum slope angle } 25^{\circ} \text {, more commonly } 35-40^{\circ} \\
\text { or greater. Minimum slope height } 150 \mathrm{~m}\end{array}$ \\
\hline Rotational slides & Moderately common. Minimum slope angle $15^{\circ}$ \\
\hline Rock block slides & Uncommon, large. Minimum slope angle $15^{\circ}$ \\
\hline Mudflows (slow earthflows) & Uncommon. Minimum slope angle $10^{\circ}$ \\
\hline Rapid soil flows & Relatively common overseas, but not in NZ. Liquefaction flows $2^{\circ}$. \\
\hline
\end{tabular}

\subsection{Rock and soil type}

Landslides during earthquakes show a strong correlation between rock type and slope (Figure 11 and Table 4, 5, and 6 ). Failures in well-jointed hard rocks such as greywacke and granite occur mainly on moderate to steep $\left(25-45^{\circ}\right)$ slopes. Slope failures in Tertiary sandstone and mudstone occur mainly on gentle to steep $\left(10-40^{\circ}\right)$ dip slopes, whereas landslides in limestone occur mainly on cliffs and escarpments. Lithology and geological structure are regarded as key factors, which together with slope configuration and steepness, control the distribution of rock falls, slides and avalanches during earthquakes.

The rock types most commonly affected by earthquakeinduced landsliding are greywacke, granite, schist, Tertiary sandstone, mudstone, limestone, alluvium, and Quaternary volcanics. Closely jointed and weathered rock masses (such as granite and greywacke) and overlying regolith and slope deposits are particularly prone to failure during earthquake, especially in steep, high-rainfall mountain areas (see Section 3 - 1929 Murchison earthquake discussion).

Failures at lower intensities (MM6) have occurred in weakly cemented Tertiary sandstone and limestone, and have been common during several earthquakes. Closely jointed volcanic rocks appear to be vulnerable to widespread landsliding only during earthquakes of M 6.0 or greater, and shaking intensities of MM7 or greater. However, creeping slopes and earth flows in mudstone or schist terrains are seldom significantly affected by earthquake shaking, possibly exhibiting a notable increase in creep velocity, but rapid large-scale catastrophic slope movements are rare.

\subsection{Climate and groundwater}

Studies of historical earthquakes suggest that climatic factors do not greatly affect the severity of earthquake-induced landsliding in New Zealand. Earthquake magnitude, depth, and location close to susceptible slopes are more important factors. However, landsliding during the 1929 Murchison earthquake was possibly worse because it occurred during a very wet winter (Dowrick, 1994). From the available data it appears that earthquake-induced landsliding in New Zealand is likely to be somewhat more severe and widespread during winter (when slopes are more saturated) than summer. Slope aspect (i.e., shady versus sunny slopes) does not appear to significantly affect landslide occurrence during earthquakes.

\subsection{Landslide size and frequency}

Data from the 22 historical earthquakes studied (Table 1) has also enabled an approximate landslide size/frequency distribution to be determined for New Zealand for the last 150 years (Table 7). The landslide size and numbers are reasonably accurate for larger slides $\left(>10^{5} \mathrm{~m}^{3}\right)$, but the numbers of smaller slides have been estimated by extrapolation, and where possible by comparison with independent studies (for example, Henderson, 1937; Adams, 1981; and Pearce and OLoughlin, 1985 for the Murchison 1929 earthquake). Table 7 shows that there are many more small landslides $\left(10^{3}-10^{4} \mathrm{~m}^{3}\right.$ or less), which commonly occur on road and rail cuts, gravel banks and terrace edges during earthquakes, than large landslides $\left(10^{5} \mathrm{~m}^{3}\right.$ or greater $)$. This trend is even more obvious if all historical earthquakes that have caused, or are likely to have caused landslide are considered (see estimated size/frequency curve in Table 7).

Based on existing information, apart from the 22 earthquakes studied so far, a number of other historical earthquakes in New Zealand of magnitude 6 or greater caused notable landsliding (Downes- 1995). During these other events most of the slides were of very small to moderately large size $\left(\sim 10^{3}-10^{5} \mathrm{~m}^{3}\right.$ or less) but few if any very large slides $\left(10^{6} \mathrm{~m}^{3}\right.$ or greater) were formed. Based on the data currently available about $99 \%$ of landslides formed during earthquakes over the last 150 years are likely to have been smaller than $10^{3} \mathrm{~m}^{3}$. The landslide distribution curve shown in Table 7 has been derived from these figures, but further studies of past and future earthquakes are needed to confirm and refine it. 
Table 6. Largest and most significant historical earthquake-induced landslides in NZ

\begin{tabular}{|c|c|c|c|c|c|c|c|c|}
\hline \multirow{2}{*}{$\begin{array}{l}\text { Landslide } \\
\text { Name }\end{array}$} & \multicolumn{3}{|c|}{ Earthquake Data } & \multicolumn{5}{|c|}{ Landslide and Topographic Data } \\
\hline & $\begin{array}{l}\text { Name / Date \& } \\
\text { (Magnitude) }\end{array}$ & $\mathrm{MM}^{1}$ & $\begin{array}{l}\text { Epi }{ }^{2} \\
(k m)\end{array}$ & Slide Type & $\begin{array}{l}\text { Approx. } \\
\text { Volume } \\
\left(\times 10^{6} \mathrm{~m}^{3}\right)\end{array}$ & $\begin{array}{l}\text { Rock } \\
\text { Type }{ }^{4}\end{array}$ & $\begin{array}{c}\text { Slope } \\
\text { Angle } \\
(0)\end{array}$ & $\begin{array}{c}\text { Slope Type and other } \\
\text { details }{ }^{5}\end{array}$ \\
\hline 1. Bruce's Lake & Wairarapa 1855 (8.2) & 9.4 & 83 & Rot slide & 11 & Tert sst/mst & 35 & Landslide pond \\
\hline 2. Falling Mt & Arthur's Pass 1929 (7.1) & 9 & 21 & Rock av & 72 & Greywacke & 37 & Mtn ridge collapse \\
\hline 3. Thompson & Arthur's Pass 1929 (7.1) & 9 & 4 & Rock av & 18 & Greywacke & 36 & Mtn ridge, Idl \\
\hline 4. Little Wanganui & Murchison 1929 (7.8) & 9.2 & 41 & Rot slide & 210 & Tert sst/mst & 20 & Old sea cliff \\
\hline 5. White Cliffs & Murchison 1929 (7.8) & 9.1 & 39 & Rot slide & 120 & Tert sst/mst & 50 & Coastal cliffs \\
\hline 6. Stanley & Murchison 1929 (7.8) & 9 & 90 & Rock av & 18 & Pal cong/volc & 30 & High mtn ridge; Idl \\
\hline 7. Matakitaki & Murchison 1929 (7.8) & $9 / 10$ & 14 & R/deb slide & 18 & Tert sst/mst & 20 & $\begin{array}{l}\text { Dip slope slide: } d / / d l \\
4 \text { deaths }\end{array}$ \\
\hline 8. Falls Creek & Murchison 1929 (7.8) & 9.3 & 38 & Rock slide & 16 & Tert sst/mst & 15 & Dip slope slide: $\mathrm{d} / \mathrm{ldl}$ \\
\hline 9. Glasseye & Murchison $1929(7.8)$ & 9.3 & 41 & Rock slide & 15 & Tert sst/mst & 17 & Dip slope slide: $\mathrm{d} / \mathrm{ld}$ l \\
\hline 10. Lower Matiri & Murchison $1929(7.8)$ & 10 & 17 & Rock slide & 12 & Tert sst/mst & 40 & Dip slope slide; Idl \\
\hline 11. Marina & Murchison $1929(7.8)$ & 10 & 32 & Rock sl/av & 11 & Granite & 32 & Steep valley side, Idl \\
\hline 12. Maruia Falls & Murchison $1929(7.8)$ & 10 & 12 & Rock slide & 4.5 & Tert sst/mst & 25 & $\begin{array}{l}\text { Dip slope slide: } \mathrm{d} / \mathrm{ldl} \\
4 \text { deaths }\end{array}$ \\
\hline 13. Maruia Valley & Murchison $1929(7.8)$ & 10 & 4 & Rock slide & 0.7 & Tert sst/mst & 28 & $\begin{array}{l}\text { Dip slope slide: } \mathrm{d} / \mathrm{ddl} \\
2 \text { deaths }\end{array}$ \\
\hline 14. Mokininui G & Murchison 1929 (7.8) & 9.7 & 25 & Rock fall/sl & $\leq 0.5$ & Granite/gwke & 37 & $\begin{array}{l}\text { Rock fall/sl in gorge } \\
2 \text { deaths }\end{array}$ \\
\hline 15. Tarakohe & Murchison 1929 (7.8) & 8 & 120 & Rock fall & $<1.0$ & Tert Imst & 75 & $\begin{array}{l}\text { Sea cliff rock fall } \\
1 \text { death }\end{array}$ \\
\hline 16. Old Mans Bluff & Napier $1931(7.8)$ & 9.8 & 17 & Rock fall/sl & 72 & Tert mst & 56 & Sea cliff collapse \\
\hline 17. Mohaka & Napier 1931 (7.8) & 9.4 & 30 & Rock fall/sl & 33 & Tert mst & $>50$ & Sea cliff collapse \\
\hline 18. Te Hoe & Napier 1931 (7.8) & 8.3 & 45 & Rock fall & 15 & Tert sst & 45 & Fall in gorge; $\mathrm{d} / \mathrm{dl}$ \\
\hline 19. McCardles & Wairoa $1932(6.9)$ & 8.6 & 30 & Rock fall/sl & $\sim 20$ & Tert sst/mst & $>55$ & Sea cliff collapse \\
\hline 20. Wairoa & Wairoa $1932(6.9)$ & 9 & 11 & Rock slide & $\sim 10$ & Tert sst/mst & 35 & Steep valley side \\
\hline 21. Buller Big Slip & Inangahua $1968(7.4)$ & 9.7 & 9 & Rock av & 5 & Granite & 31 & Slide in gorge; $\mathrm{d} / \mathrm{ldl}$ \\
\hline 22. Ram Creek & Inangahua 1968 (7.4) & 9.8 & 12 & R/deb slide & 5 & Granite & 38 & Small valley; d/ldl \\
\hline 23. Jackson's & Inangahua 1968 (7.4) & 10 & 11 & Rock fall/sl & 0.2 & Tert Imst & 65 & $\begin{array}{l}\text { Steep cliff near house } \\
1 \text { death }\end{array}$ \\
\hline \multicolumn{9}{|c|}{$\begin{array}{l}\text { NOTES: } \\
\text { 1. Modified Mercalli (MM) Felt Intensity. } \\
\text { 2. Distance }(\mathrm{km}) \text { from epicentre (Epi) to landslide. } \\
\text { 3. Landslide type abbreviations: rotational slide (rot sl); rock avalanche (rock av); slide (sl); debris (deb). } \\
\text { 4. Rock types: Tertiary sandstone and mudstone (Tert sst/mst), limestone (Imst), Greywacke (gwke); conglomerate (cong). } \\
\text { 5. Other abbreviations: Landslide dammed lakes (Idl), drained (breached)or infilled landslide-dammed lake (d/ldl). }\end{array}$} \\
\hline
\end{tabular}


Table 7. Size/frequency distribution for historic earthquake-induced landslides in NZ

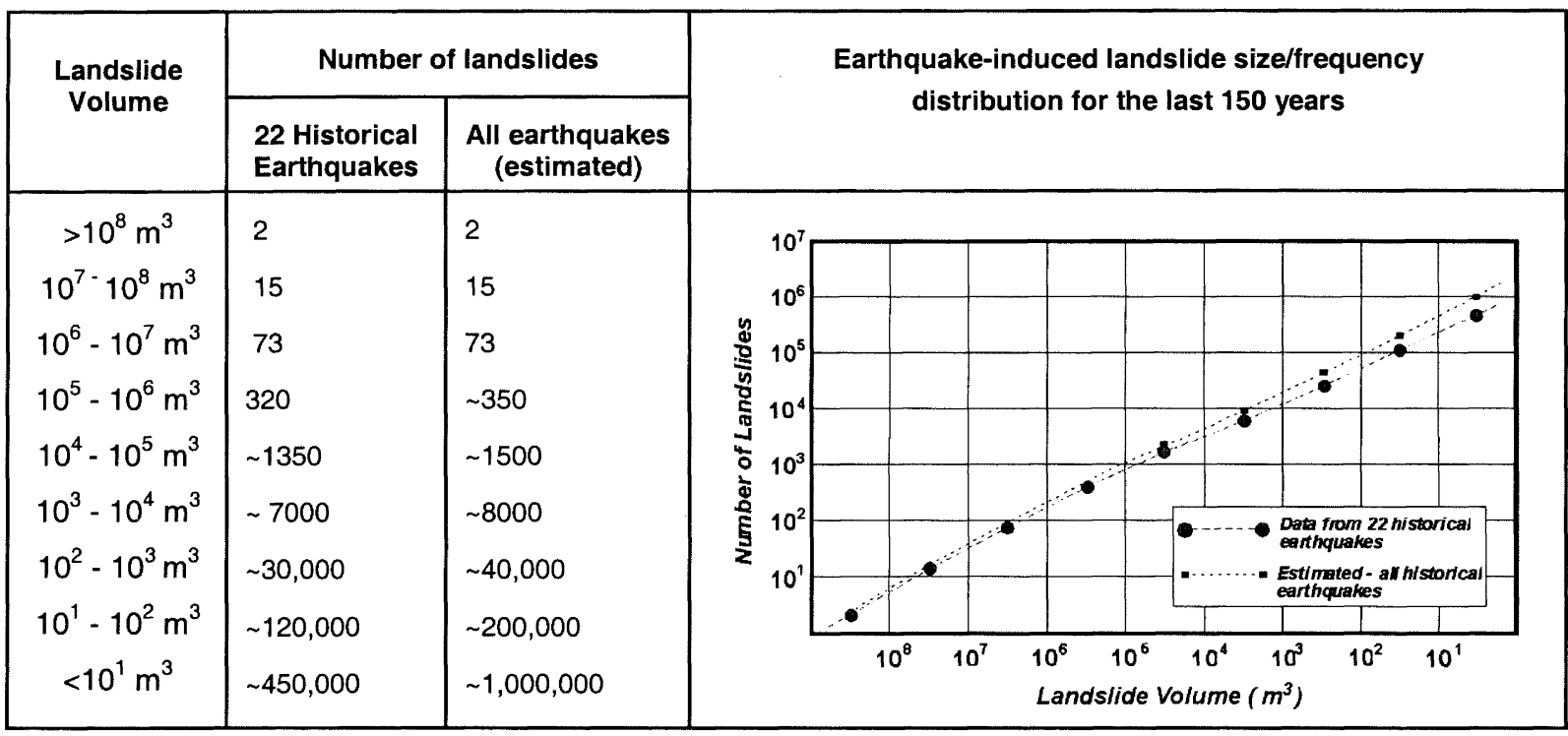

\section{LANDSLIDING AND MM INTENSITY}

As already discussed, revisions of the New Zealand MM intensity scale in 1991 (Study Group of the NZNSEE, 1992) and 1996 (Dowrick, 1996) clarified structural damage criteria but not environmental effects such as landslides and liquefaction. However, better definition of environmental response criteria in the MM scale was a primary objective and outcome of the 1997 study (Hancox et al., 1997). Changes to the environmental criteria in the MM scale recommended on the basis of that study are summarised and discussed below.

\subsection{Revised New Zealand MM Intensity Scale}

The 1997 study of 22 historical earthquakes enabled the environmental criteria in the New Zealand MM intensity scale to be expanded and described in more detail. Primarily, this involved comparing the nature and extent of landsliding and ground damage in $\mathrm{MM}$ isoseismal zones determined from building damage, and establishing general landslide characteristics for different intensity levels. For some older earthquakes this process allowed intensity maps based on landsliding to be confirmed or modified (e.g., Wairarapa 1955, Murchison 1929), and intensities to be assigned in areas where there were few buildings (e.g., Arthur's Pass 1929 and 1994 earthquakes). Table 8 shows the 1996 version of the MM scale together with the new environmental criteria that are suggested. In comparing the 1996 and proposed new versions there are few major points of difference, except that the revised criteria are more complete and detailed. It is hoped that the expanded criteria will lead to more certainty and consistency in assigning MM intensities from earthquake ground damage. The main features of the revised environmental criteria proposed for the New Zealand MM scale are: (a) MM6: Very small landslides, soil and rock falls may occur, along with minor liquefaction effects (sand boils).

(b) MM7: Significant small to moderate landslides occur, and liquefaction effects (sand boils) common in susceptible areas.

(c) MM8: Widespread small-scale landsliding and a few moderate to very large failures occur, together with small landslide-dammed lakes, sand boils, and localised lateral spreads along rivers and streams.

(d) MM9/10: Widespread, damaging large to extremely large landslides; sand boils are widespread on alluvium, and lateral spreading common, with cracking and fissuring parallel to river banks and waterfront areas; landslide-dammed lakes often formed in susceptible terrain.

It is notable that there are only two confirmed cases of MM10 shaking in New Zealand, i.e. 1931 Napier and 1968 Inangahua in the near source zone. As already mentioned, MM10 was assigned in the 1997 study to two other events (1855 Wairarapa and 1929 Murchison) based solely on landslides, as there were no buildings in the near source (epicentral) zone.

As well as the 4 events with MM10 noted above, only 3 other historical earthquakes were large and shallow enough to cause MM10, these are 1848 Marlborough, 1888 North Canterbury, and 1934 Pahiatua. Although the lack of buildings in the epicentral areas of these events prevented MM10 from being assigned, the landsliding associated with these events. suggests that MM10 shaking may have occurred. 
However, the landslides caused by these events were less notable, possibly because they were in areas of less susceptible terrain and geology (e.g., low hill country, alluvial plains). Extensive and large landslides in the mountains near Arthur's Pass were also used to establish a MM9 zone for the 1929 Arthur's Pass $M_{s} 7.1$ earthquake, but this event was probably not large enough to cause MM10.

Although construction response criteria in the MM intensity scale have been developed for MM11 and MM12, shaking at these levels has not been reported in New Zealand, and the probability of shaking greater than MM10 occurring in an urban area in this country is considered to be low. (Dowrick, 1996). For these reasons, environmental response criteria for MM11 and MM12 are not proposed. However, earlier versions of the MM intensity scale (Study Group of the NZNSEE, 1992) suggest that environmental responses at MM11 and 12 are similar to the new criteria proposed for MM9 and 10 (with "large rock masses displaced" at MM12), but are possibly more widespread and severe.

\subsection{Environmental criteria in other earthquake intensity scales}

There are several other intensity scales for describing felt intensity shaking effects. Of the intensity scales commonly used today, the MM scale is generally the most widely used in the English-speaking world, and only the Japanese (JMA) scale differs greatly from it. The JMA scale has few environmental criteria, referring to "numerous landslides, embankment failures, and fissures on flat ground" at JMA VI ( MM9). The Rossi-Forel scale does not distinguish between separate levels of severe damage to structures or the environment, and has fallen from use. The Chinese scale is almost identical to the MM scale, while the Medvedev, Sponheuer and Karnik (MSK) version is a slight modification of the MM scale. In 1992 the MSK scale was renamed the European Macroseismic Scale (EMS), but in terms of construction damage criteria it remains generally similar to the MM scale level-for-level (Dowrick, 1996). Table 9 shows a comparison of the intensity levels included in some of these scales (after Krinitzsky and Chang, 1988).

Environmental criteria are quite well defined within the MSK scale (summarised below), being broadly similar to those in the revised MM scale (Table 8). However, the proposed new environmental criteria are more detailed and complete, and are expected to be better for assigning MM felt intensities from landsliding in New Zealand.

\section{Environmental criteria in the MSK Scale}

MSK VI: $\quad$ Narrow cracks (up to $100 \mathrm{~mm}$ ) in wet ground, occasional landslides in mountains.

MSK VII: Isolated falls from sandy and gravelly banks.

MSK VIII: Small landslips in hollows and embankments; cracks several cm in ground
MSK IX: On flat land overflow of water, sand, and mud often observed (liquefaction effects); ground cracks to widths of up to $100 \mathrm{~mm}$; falls of rock, many landslides and earth flows.

MSK X: $\quad$ Cracks in ground up to several decimeters and sometimes $1 \mathrm{~m}$ wide. Broad fissures occur parallel to water courses. Loose ground slides from steep slopes. Considerable landslides are possible from river banks and steep coasts. In coastal areas, displacements of sand and mud; new (landslide-dammed) lakes formed.

MSK XI+: $\quad$ Ground fractured considerably by broad cracks and fissures, slumps and spreads; numerous landslides and falls of rock. Other effects similar to $M M X$, but more severe.

\section{GROUND CLASSES}

A range of Ground Classes of varying landslide vulnerability (similar to those used for buildings) has been developed so that more consistent and reliable earthquake intensities can be assigned in areas where there were few buildings. Five provisional Ground Classes are proposed to indicate landslide susceptibly and intensity effects in areas of different terrain and rock types. These classes and their susceptibility to earthquake-induced landsliding are defined as follows:

\section{Class I}

(a) Bedrock - hard to firm rocks, relatively massive (unbedded), both widely and closely jointed, indurated greywacke and granitic rocks, moderately weathered to fresh, with thin $k<1-2$ m) surficial colluvial materials, on gentle to moderate slopes $\left(15-30^{\circ}\right)$. Also, firm older alluvial deposits (gravels) forming high terraces (not terrace edges). This class is the benchmark against which other ground classes can be compared.

(b) Supported cut slopes in bedrock; engineered fills on firm ground.

Landslide susceptibility Low - very low

Class II

Bedrock - well bedded, slightly to moderately weathered Tertiary sandstone, mudstone, and limestone dipping down slope on gentle to moderate slopes (15-30 dip slopes), with thin regolith and surficial deposits. Also firm to stiff soils.

Landslide susceptibility: Moderate-high

Average change in MM intensity from Class l: $+0.5-1$

\section{Class III}

Bedrock - well jointed indurated greywacke and granitic rocks, moderately to highly weathered, with thick $(>5 \mathrm{~m})$ regolith and colluvium on high, steep to very steep (say $35-50^{\circ}$ ) slopes, and on high narrow ridges (near and far field). Also low gravel banks and terrace edges, scree deposits, and slopes and cuts formed in loose unconsolidated deposits.

Landslide susceptibility: High-Very High

Average change in MM intensity from Class I: +1 - $\quad 1.5$ 
Table 8. Proposed environmental criteria for the $\mathrm{N} Z$ Modified Mercalli Intensity Scale

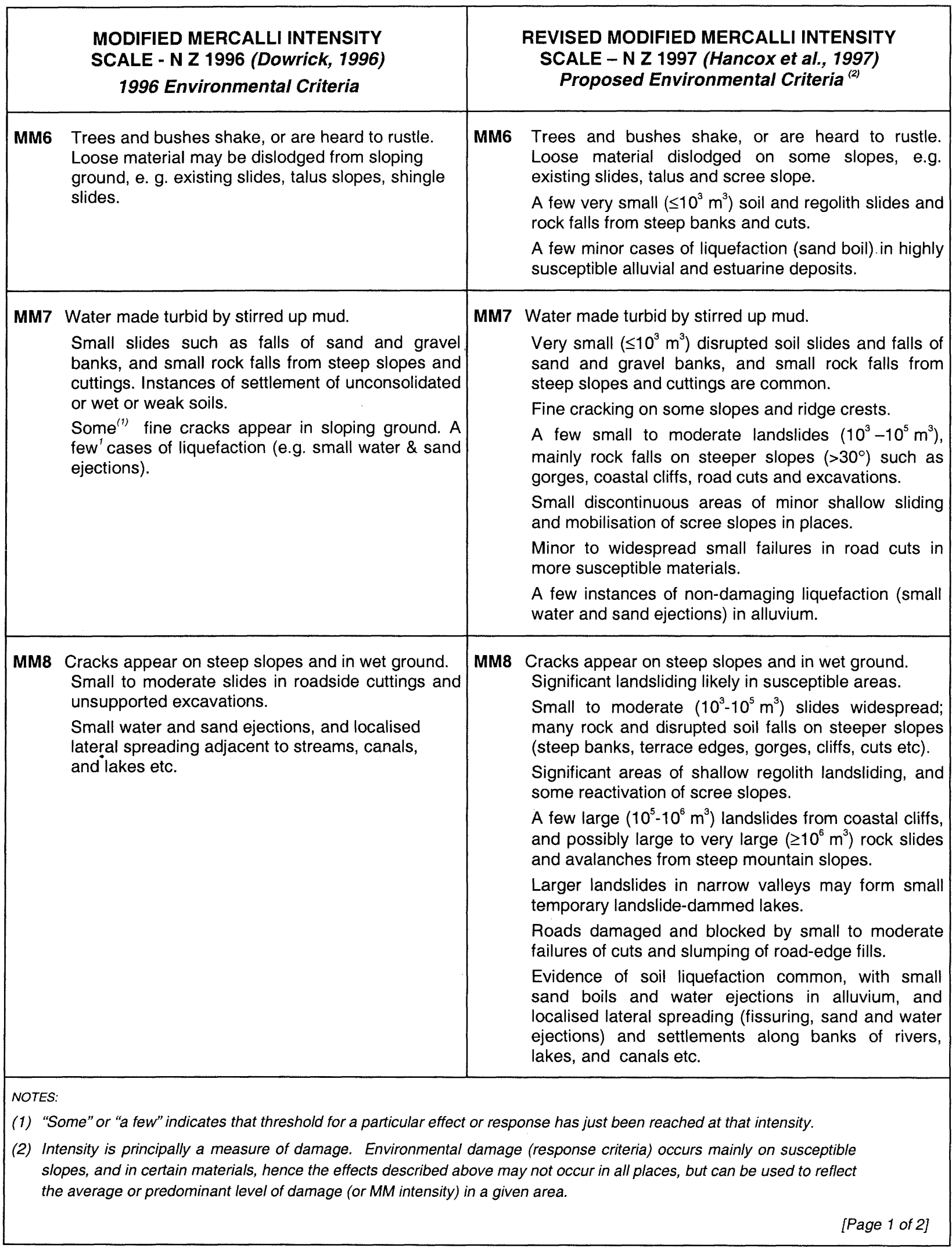


Table 8 continued

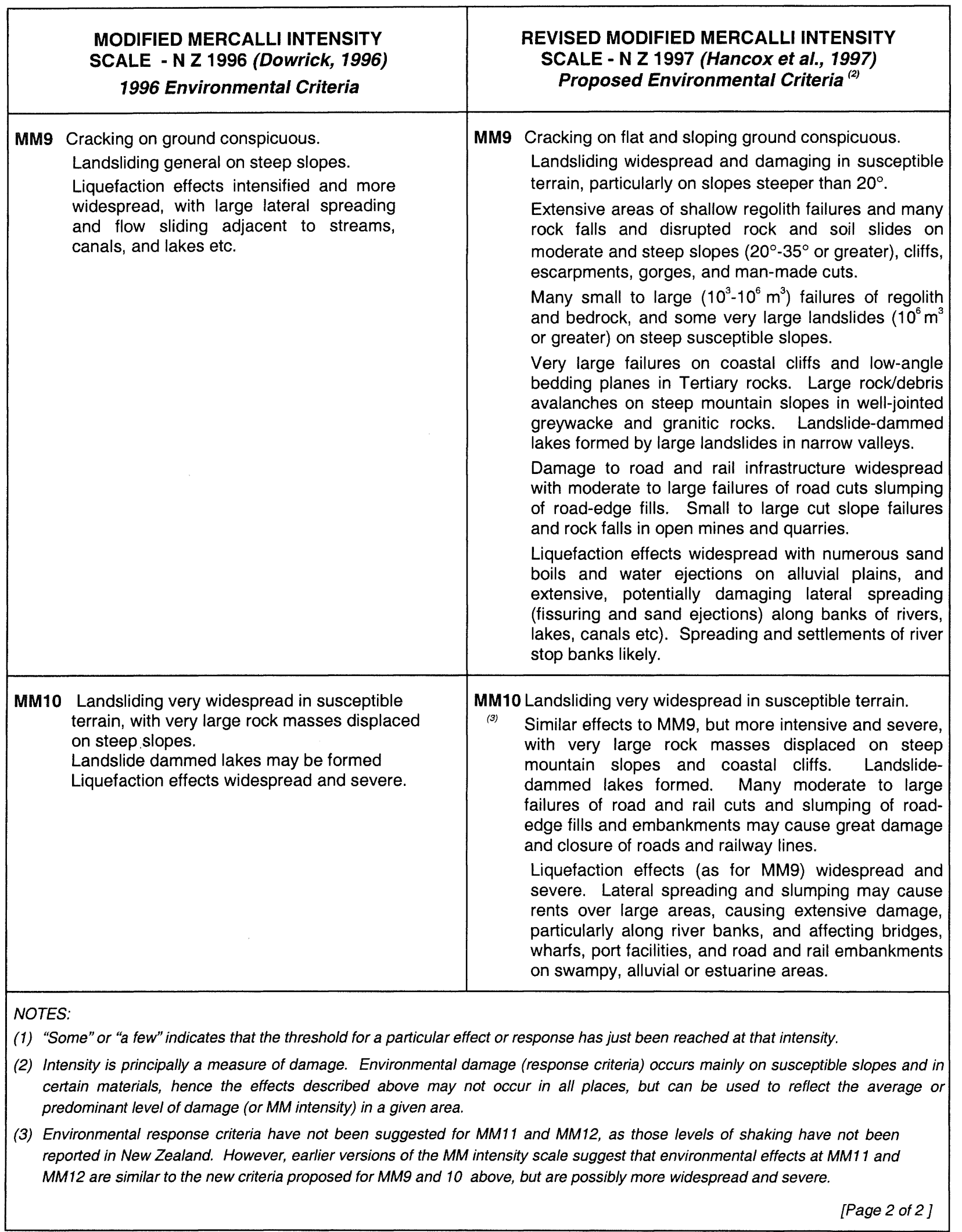


Table 9. Comparison of earthquake intensity scales (after Krinitzsky and Chang, 1988)

\begin{tabular}{|c|c|c|c|c|}
\hline $\begin{array}{l}\text { Modified } \\
\text { Morcalll } \\
\text { (MM) }\end{array}$ & $\begin{array}{c}\text { Japanese } \\
\text { Metrologica } \\
\text { Agency } \\
\text { (JMA) }\end{array}$ & $\begin{array}{l}\text { Peoples } \\
\text { Republic } \\
\text { of China }\end{array}$ & $\begin{array}{l}\text { Rossi - } \\
\text { Forel } \\
\text { (RP) }\end{array}$ & $\begin{array}{c}\text { Medvedev, } \\
\text { Sponheuer, } \\
\text { Karnik } \\
\text { (MSK) } \\
\end{array}$ \\
\hline 1 & \multirow{3}{*}{1} & I & \multirow{2}{*}{$\frac{1}{11}$} & $T$ \\
\hline 2 & & "I & & II \\
\hline 3 & & III & III & III \\
\hline 4 & \multirow{2}{*}{$\frac{\text { II }}{\text { III }}$} & IV & IV & IV \\
\hline 5 & & $v$ & $v$ & $\mathbf{v}$ \\
\hline 6 & IV & VI & VII & vi \\
\hline 7 & \multirow{2}{*}{$v$} & VII & VIII & VII \\
\hline 8 & & VIII & \multirow{2}{*}{$1 X$} & VIII \\
\hline 9 & \multirow{2}{*}{ VI } & IX & & IX \\
\hline 10 & & $x$ & \multirow{3}{*}{$x$} & $x$ \\
\hline 11 & \multirow{2}{*}{ VII } & $\mathbf{x} 1$ & & $\mathbf{X I}$ \\
\hline 12 & & $x \|$ & & x।I \\
\hline
\end{tabular}

\section{Class IV}

(a) Areas of very steep $\left(>45^{\circ}\right)$ natural slopes (such as cliffs, escarpments, gullies, and gorges) in hard, jointed rocks, weak Tertiary rocks, and also weakly-cemented Quaternary deposits (loess, pumice).

(b) Unsupported high $\left(>3-6 \mathrm{~m}\right.$ ), very steep (say $>60^{\circ}$ ) cuts and excavations in harder bedrock and soft rocks, especially those cuts capped with 1-3 m of soils and regolith deposits, and not designed to withstand the effects of seismic shaking.

Landslide susceptibility: High-very high

Average change in MM intensity from Class I: $+1-2$

\section{Class $V$}

Loose, saturated, unconsolidated, fine-grained, alluvial, estuarine and marine deposits (fine sand, silt), and other soft sediments, non-engineered fills and reclamations on flat, low-lying terrain and gentle slopes $\left(<10^{\circ}\right)$.

Landslide susceptibility:

High-very high

Average change in MM intensity from Class I - Near field ':

$$
+0.5 \text { - } 1
$$

Low frequency shaking - Far field ${ }^{1}(>M 7.2$ earthquakes):+ $1-3$

\section{The extent (radius, $\mathrm{km}$ ) of the Near Field and maximum epicentral MM Intensity varies with earthquake magnitude, as follows:}

\section{5.0 - $5 \mathrm{~km}$ (MM6); M5.5 - $15 \mathrm{~km}$ (MM7); $M 6.0$ - $25 \mathrm{~km}$ (MM8); \\ M 6.5 - 35km (MM9); $M 7.0$ - 40km (MM10); $M 7.5$ - 45km (MM11) (after Krinitzsky and Chang, 1988)}

The 1997 study (Hancox et al., 1997) stressed that these Ground Classes were based on subjective landslide data used in that study, and were considered provisional, pending further studies. However, the proposed classes are broadly consistent with those of Van Dissen et al. (1992) in their earthquake and ground shaking hazard assessment in Wellington. For example, on soft and or loose, saturated ground (proposed Class V), Van Dissen et al. (1992) suggested MM shaking intensity increases (compared to greywacke bedrock) of plus 1-2 for near field, and plus 2-3 for far field effects. Such increases may result from frequency-dependent ground motion amplification (resonance effects), and also increased duration of strong shaking duration, which on soft ground during large earthquakes may be more than 2-3 times greater in the near and far field respectively.

A continued vigorous programme of $\mathrm{MM}$ intensity reporting in New Zealand was recommended in the NZSEE reconnaissance report on the 2001 Nisqually earthquake (Beetham et al., in press). The use of the landslide MM criteria as described here will benefit hazard assessments during future earthquakes in New Zealand, and facilitate MM reporting over wide areas where there are few buildings. By comparison, strong motion recorders provide only a general indication of ground shaking intensity in some areas. Felt intensity observations offer valuable additional earthquake data.

More detailed studies of several selected earthquakes are needed to refine and establish more definitive criteria for these classes, correlation with strong motion records, and their use within the MM scale in New Zealand. Although comprehensive studies of important earthquakes have yet to be undertaken, the results of a recent study of the 1942 Wairarapa earthquakes (Downes et al., 1999) were generally consistent with landslide/MM relationships and Ground Classes established in the 1997 study

\section{EARTHQUAKE-INDUCED LANDSLIDE OPPORTUNITY}

The 1997 study showed that the distribution of earthquakeinduced landslides in New Zealand is strongly linked to regional seismicity, with historical failures concentrated mainly in areas of high seismicity where moderate and large earthquakes occur more frequently (Figure 1). Potentially damaging landslides were shown to be triggered by shallow (depth $<45 \mathrm{~km}$ ), longer-duration earthquakes of magnitude 6 or greater, which are more likely in the hilly areas of northwest Nelson, the central Southern Alps, Fiordland, Marlborough, Wellington, Wairarapa, Hawke's Bay, and East Cape. These areas are more likely to undergo earthquake shaking strong enough to trigger landslides, and therefore have higher earthquake-induced landslide opportunity. In this context, the term opportunity is used in the same sense as it is commonly used for assessing liquefaction potential (= susceptibility + opportunity), where opportunity relates to the occurrence of seismic shaking strong enough to initiate liquefaction of susceptible soils (Hansen and Franks, 1991).

Fewer landslide-triggering earthquakes occur in the central North Island, Auckland, Northland, Canterbury and Central Otago, and Southland, so the earthquake-induced landslide opportunity (and hazard) is generally regarded as lower in those areas. These findings are generally reflected in a recently developed probabilistic seismic hazard (PSH) model for New Zealand (Stirling, 2000; Stirling et al., submitted manuscript, 2001). Maps derived from the PSH model show peak ground acceleration (PGA) at different levels of probability on "Class B sites" (stiff to intermediate soils) indicate that the highest earthquake-shaking hazard in New Zealand is in the western to northern South Island, and in the eastern North Island.

Figure 12a shows the new PSH model of Stirling et al. (2001) with PGA (g) expected at 150 Year Return Time on "Class 
B" stiff to intermediate soil sites (McVerry et al., 2000). The so-called "Class B" sites are essentially stiff soil sites or rock sites mantled by more than $3 \mathrm{~m}$ of soil (New Zealand Loadings Standard NZS4203:1992). Although most hill slopes in New Zealand are underlain by Class $A$ materials (rock or very stiff solls), in this analysis it was considered more appropriate to model for Class $B$ conditions, given the collective effects of the regolith mantle (top soll, colluvium, and weathered bedrock), slope angle, and topographic amplification of earthquake shaking on slopes.

The Stirling et al. PSH model has been used to develop an earthquake-induced landslide (EIL) opportunity model for New Zealand for a 150 Year Return Time (Figure 12b). This model has been derived by integrating the ElL felt intensity (MM) relationships (described earlier) with predicted levels of PGA indicated by the Stirling (2000) PSH model, as illustrated in Table 10.

Table 10. Definition of earthquake-induced landslide opportunity from PGA values

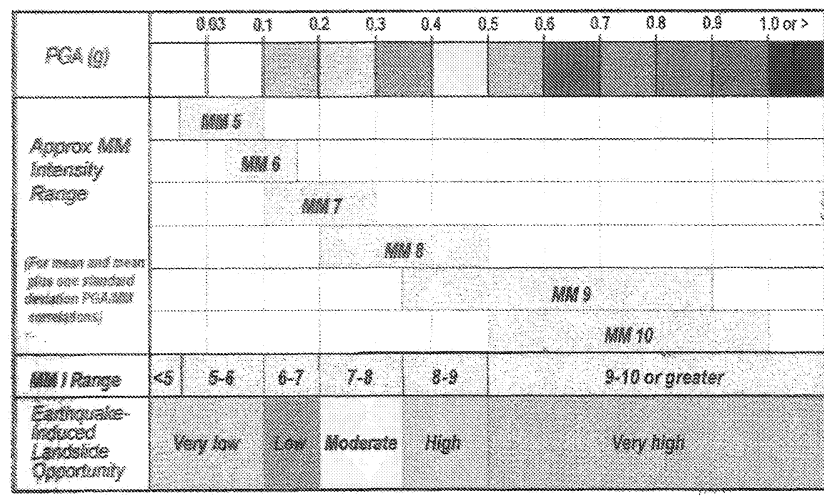

Five classes of relative EIL opportunity are recognised (very low, low, moderate, high, and very high). These have been derived using EIL/MM relationships in New Zealand (Hancox et al., 1997) together with an approximate MM/PGA relationship range based on the mean and mean plus one standard deviation correlations of Murphy and OBrien (1977).

The ELL Opportunity classes define the relative likelihood of earthquake-induced landslides occurring in areas of different earthquake shaking (PGA), based on the ground damage effects established for MM intensity shaking in New Zealand (discussed in Section 4). That is, given a certain level of PGA (or MM intensity), the EIL Opportunity classes indicate the relative probability that landsliding will occur, and its nature and extent.

Similar ELL opportunity maps can be derived using MM intensity maps (based on the Stirling et al. PHS model) currently being developed for different return periods (pers. comm. W Smith, 2001), but are not yet available for the ELL opportunity model.

The earthquake-induced landslide opportunity classes (Table 10 and Figures $12 \mathrm{~b}$ and $13 \mathrm{~b}$ ) have been defined on a 5 -fold scale. Typical landslide and ground damage effects that can be expected on susceptible slopes (mostly $>30^{\circ}$ ) and ground, as follows:

1. Very Low $(\leq M M 5 * 6)$ : Very small rock and soil falls on the most susceptible slopes.

2. Low (MM6-7): Small landslides, soil and rock falls may occur on more susceptible slopes (particularly road cuts and other excavations), along with minor liquefaction effects (sand boils) in susceptible soils.

3. Moderate (MM78): Significant small to moderate landslides are likely, and liquefaction effects (sand boils) expected in susceptible areas. Noticeable damage to roads (more significant in higher classes).

4. High $(\mathbf{M M} 8 \cdot 9)$ : Widespread small-scale landsliding expected, with a few moderate to very large slides, and some small landslide-dammed lakes; many sand bolls and localised lateral spreads likely.

5. Very high ( $\geq M M 9)$ : Widespread landslide damage expected. Many large to extremely large landsides; sand boils are widespread on allwium, and lateral spreading common along river banks; landslide-dammed lakes are often formed in susceptible terrain.

The EIL Opportunity model (Figures $12 b$ and 13b) shows that the areas of highest opportunity for earthquake-induced landsliding correspond to the higher PSH zones in the western and northern South Island and eastem North Island. By contrast, the areas of lowest ELL opportunity are in the northem North Island and southeastern South Island. This is consistent with the overall distribution of significant historical earthquake-induced landslides in New Zealand (Figure 1).

The main areas in which such landslides occurred in the last 150 years fall within the Moderate, High, and Very high EIL Opportunity zones, with few or no slides recorded in Low and Very low zones in the northern North Island and southeastern South Island (Figure 12b)

A similar ELL Opportunity trend is predicted for 475 Year Retum Time earthquake shaking (Figure 13a), except that the High and Very High zones are considerably more extensive (Figure 13b). This probably reflects the relatively high probability of future strong ground shaking associated with large earthquakes on some major active faults (e.g., the Alpine Fault, Marlborough faults, and Wellington Fault) and the Subduction Zone within the next 500 years. 


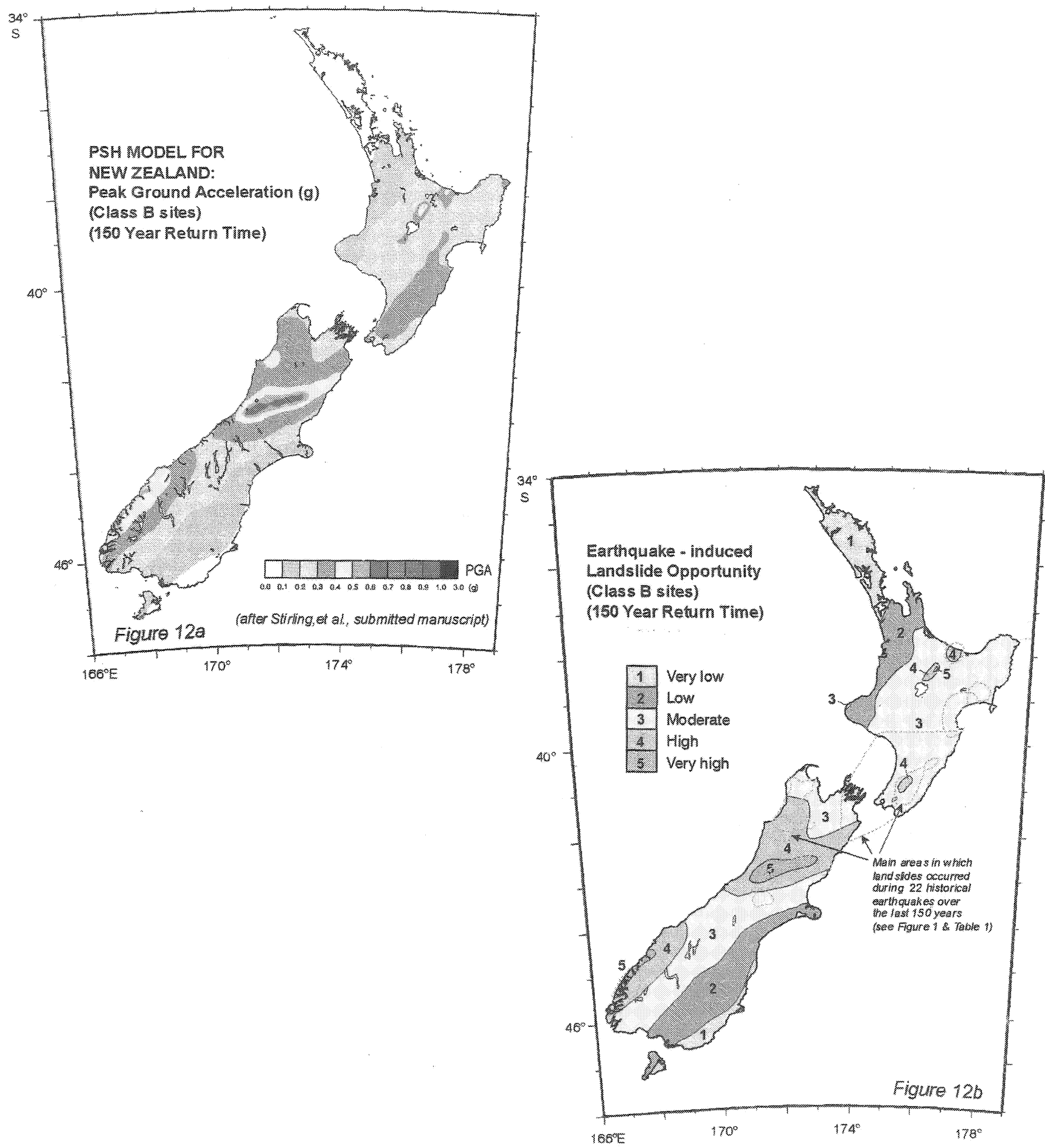

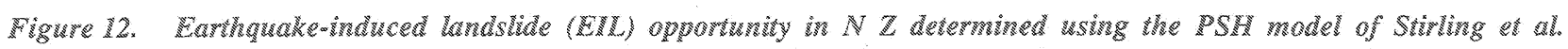
(2001). Figure 12 a shows peak grownd accelerations (PGA, g) at 150 Year Retum Tine on AClass B $\equiv$ (stiff to internediate) soils. Five zones of ELL opportunity (very low, low, noderate, high, and very high) were derved by relating PGA to ELIMM relationships in $N Z$ (Figure $12 b$ and Table 10). In this model, areas of highest ELL opportunty correspond to areas of higher PGA (PSH) in the western and rorthern Sowh Lsland, and eastern North Lsland. Areas of lowest ELL opportunity are in the northern North Island and southeastern Sowth Island. This is consistent with the distribution of historical earhquake-indwced landslides in New Zealand (Figure 1). 

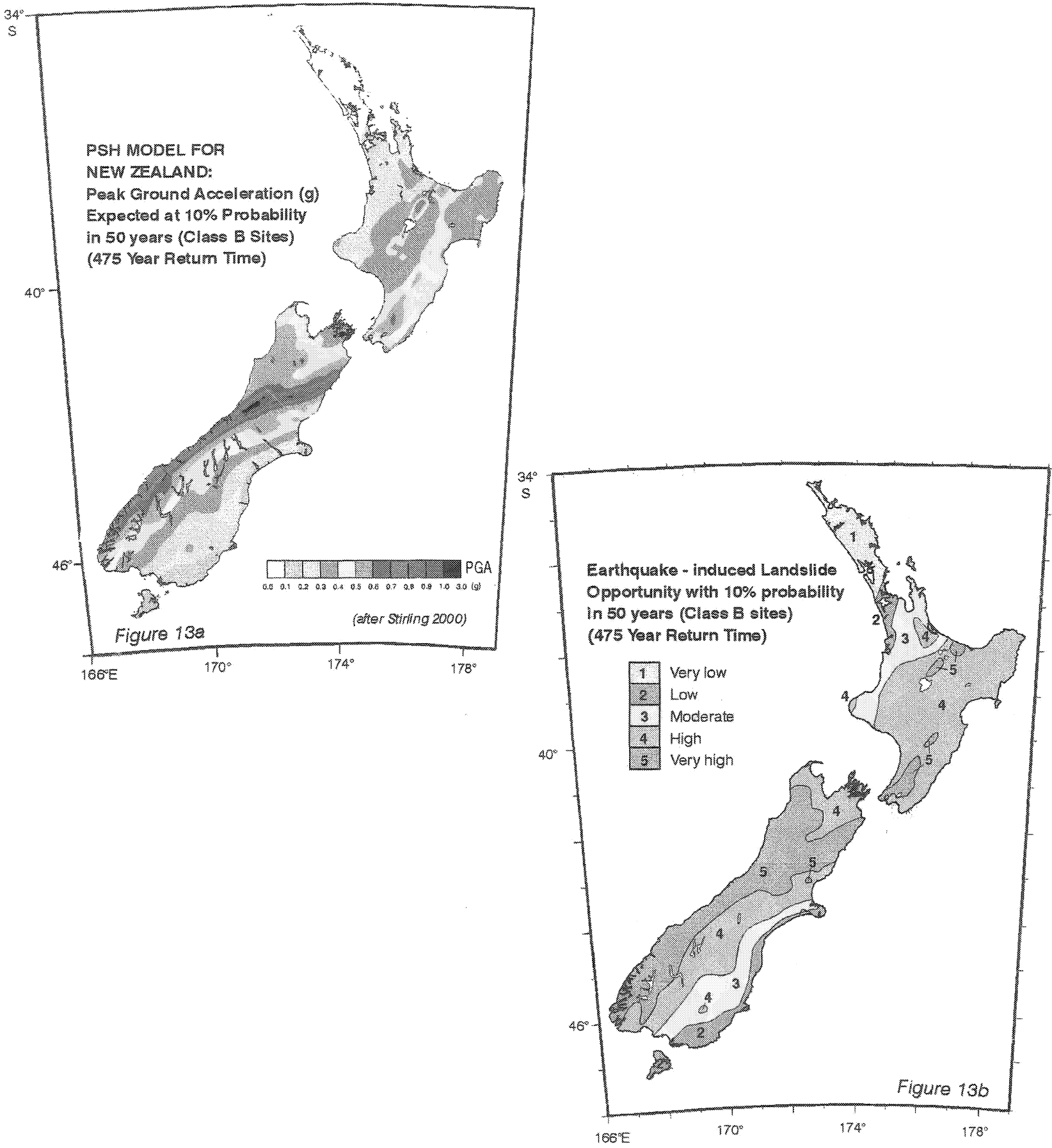

Figure 13. Earhquakeminduced landslide (EIL) opportunity in $\mathrm{NZ}$ determined using the PSH model of Stirling (2000). Figure $13 a$ shows peak grownd accelerations (PGA, g) at $10 \%$ probability in 50 years ( 475 Year Retwrn Thme) on "Class B" (stiff to intermediate) soils. Five zones of EIL opportunity (very low, low, moderate, high, and very high) were derived by relating PGA to ELLMM relationships in $N Z$ (Figure $13 b$ and Table 10). In this model, areas of highest ELL opportunity correspond to areas of higher PGA (PSH) in the western and norihern South Island, and eastern North Island. Areas of lowest EIL opportunity are in the northern North Island and southeastern South Island. This is consistent with the distribution of historical earthquake-induced landsides in New Zealand (Figure 1 and Figure 12b). 


\section{LANDSLIDE HAZARD MODEL}

The 1997 study and recent development of an EIL Opportunity model has allowed relationships to be developed for earthquake-induced landsliding and its distribution in New Zealand, and provided the basis for assessing landslide hazard and risk in different areas during future earthquakes. The EIL opportunity model is currently being further developed, and will be integrated with a GIS-based landslide susceptibility model as one step in developing a probabilistic landslide hazard model for New Zealand.

By selecting and weighting the main landslide-causing factors (slope angle, rock and soil types) a model can be developed using GIS to predict (or zone) how susceptible different parts of the country are to landsliding during common triggering events. Generally these will be moderate to large shallow earthquakes (M6 or greater at depths $\leq 45$ $\mathrm{km}$ ), and also very heavy or prolonged rainfall (for example, $\geq 200 \mathrm{~mm}$ in 24 hours or less). Some of this research has been started in the last two years with development of an EIL opportunity model. A preliminary Landslide Susceptibility Model for New Zealand $(1: 1,000,000)$ has already been developed and used in an earthquake loss modelling study (Smith et al., 2001). This model is currently being refined with the addition of a complete landslide layer, and revised layers for other factors following testing against known landslide distributions and terrain modelling. It will eventually be integrated with the EIL Opportunity model to develop a probabilistic EIL hazard model for New Zealand.

Determination of regional earthquake-induced landslide susceptibility has also recently been used overseas in assessing potential hazard and loss during earthquakes (HAZUS, 1997). In the HAZUS methodology, susceptibility is characterised by three main factors - geology, slope angle, and critical acceleration. Critical acceleration is the level of shaking required for slope failure during an earthquake (Wilson and Keefer, 1985), and is a complex function of geology, slope, and earthquake shaking, together with groundwater.

In the HAZUS (1997) methodology, two extremes of groundwater condition are considered: (a) dry slopegroundwater below the surface of sliding; (b) wet slopegroundwater level at (or close to) the ground surface. These extremes require different levels of shaking for landsliding to occur. For example, a $30^{\circ}$ slope in strongly cemented rocks requires a critical acceleration of $0.4 \mathrm{~g}$ (MM8-9) for failure when dry, but only $0.12 \mathrm{~g}$ (MM6-7) when wet. By contrast, a $10^{\circ}$ slope in weak mudstone and clayey soils require $0.18 \mathrm{~g}$ (MM 6-7) for failure when dry, but < 0.03 (MM 4-5) when the slope is wet. These examples illustrate a simplified methodology for estimating levels of shaking required for earthquake-induced landsliding.

Although, a generally accepted relationship of earthquake shaking to landslide initiation has not yet been developed for the HAZUS (1997) methodology, its general principals appear to be borne out by studies of earthquake-induced landsliding in New Zealand (Henderson, 1937; Hancox et al., 1997). Further research is needed, however, to modify and test the HAZUS (1997) methodology for earthquake-induced landslide hazard assessment in New Zealand. This will probably involve using PGA values estimated from MM intensity data, as there are few instances of landsliding during earthquakes that can be reliably associated with earthquake strong motion (PGA) records in New Zealand.

\section{DISCUSSION}

The 1997 and subsequent studies of earthquake-induced landsliding described here have provided a much better understanding of landslides and ground damage caused by the 22 most significant historical earthquakes in New Zealand. Although it has not yet been possible to examine in detail other earthquakes likely to have caused landsliding in the last 150 years, the relationships that were determined between landsliding and earthquake magnitude and MM felt intensity are considered to be generally representative of historical EIL in New Zealand. These relationships are similar to those determined for overseas earthquakes by Keefer (1984 a), except for slightly higher EIL threshold levels in New Zealand for earthquake magnitude (M 5 rather than M 4) and felt intensity (MM 6 rather than MM5).

The EIL relationships and proposed new environmental response MM criteria will benefit future earthquake hazard assessments in New Zealand, while better knowledge of the many large prehistoric landslides, as suggested by Adams (1981), will support paleoseismic studies. Although many large landslides and landslide-dammed lakes in New Zealand have been formed during earthquakes, some many wellknown large landslides were not associated with any earthquake (e.g., Abbotsford 1979, Mt Cook 1991, Mt Adams 1999). Therefore, it is difficult to prove an earthquake origin for a particular landslide on the basis of one slide alone. However, the occurrence of a group of large landslides of about the same age (based on radiometric dating, vegetation chronology, and geomorphology) is strong evidence of a prehistoric earthquake. The EIL relationships defined here can then be used to estimate the location and size of the earthquake, and when it occurred can be inferred from the age of the landslides.

Crozier et al (1995) established seismic triggering of a group of coeval prehistoric landslides in the North Island by taking into account event synchronicity, modern analogues, location, and limiting equilibrium back analysis.

The principal arguments hinged on modern analogues, which indicate that seismicity and climate (heavy rainfall) are the only triggering factors that produce large clusters of individual landslides. Historical landsliding in New Zealand show that both these triggering agents produce widespread clusters of small, rapid shallow landslides. Heavy rainfall may produce isolated large deep-seated landslides, but apparently only moderate and large earthquakes produce coeval clusters of large deep-seated landslides. The spatial distribution of the landslide cluster is also important, and if centred on or close to a major fault line a case may be argued for the causative earthquake originating on that fault.

The 1997 EIL study showed an obvious lack of historical earthquake-induced landslides along the central Southern Alps to northern Fiordland. However, previous studies (Adams, 1981; Perrin and Hancox, 1992; Hancox and Perrin, 1994) and the GNS database of large landslides indicate the 
presence of numerous large, prehistoric, apparently synchronous landslides, based on their geomorphology and vegetation cover. Geomorphic and paleochronological studies (radio carbon, tree-ring, lichenometry, and weathering rind dating) could be undertaken to establish the age of these landslides. It would then be possible to estimate the age, location, and magnitude of recent earthquakes (in relation to the Alpine Fault and other major active faults in the region), using data and relationships established from the 1997 study.

Further studies that could be undertaken to further improve our understanding of earthquake-induced landslide hazard and risk in New Zealand include: (a) detailed studies of specific earthquakes (Marlborough 1848, Wairarapa 1855, Napier 1931, Pahiatua 1934); (b) refinement of EIL Ground Classes; (c) paleoseismic studies in known 'seismic gaps' on major active faults, such as the central Alpine Fault, and southern White Creek Fault; and (d) continued earthquake reconnaissance studies in New Zealand and overseas. Studies of clusters of large prehistoric landslides along the Southern Alps and northwest Nelson could help determine the past earthquake history of those active faults and aid future seismic hazard assessments in the region.

\section{CONCLUSIONS}

(1) Recent studies of landsliding and ground damage caused by 22 historical earthquakes have enabled relationships between landslide distribution and earthquake magnitude, epicentre, MM isoseismals, fault rupture zone, topography, and geology to be defined for New Zealand. A preliminary landslide size/frequency distribution for the last 150 years has also been determined, but studies of other earthquakes are needed to confirm and refine it.

(2) Threshold levels have been derived for earthquakeinduced landsliding in New Zealand. The minimum magnitude for landsliding is about M 5, with significant landsliding occurring at M 6 or greater. The minimum MM intensity for landsliding is MM6, while the most common intensities for significant landsliding are MM7 and 8 .

(3) The intensity threshold for soil liquefaction in New Zealand was found to be MM7 for sand boils, and MM8 for lateral spreading, although such effects may also occur at one intensity level lower in highly susceptible materials. The minimum magnitude for liquefaction phenomena in New Zealand is about M 6, compared to M 5 overseas where highly susceptible soils are probably more widespread.

(4) Revised environmental response criteria and Ground Classes are proposed for the New Zealand MM intensity scale based on landsliding and liquefaction ground damage. It is hoped that the new criteria and ground classifications will make it easier to assign felt intensities based on landsliding and ground damage, especially in areas where there are few buildings, and also benefit future assessments of earthquake hazard and risk assessments. Newly established relationships between earthquake-induced landsliding and earthquake magnitude and MM intensity will also enhance seismic hazard studies in New Zealand, enabling landslide damage during future earthquakes to be predicted with more confidence, and providing another means of studying prehistoric earthquakes in different areas.

(5) A continued vigorous programme of $\mathrm{MM}$ intensity reporting in New Zealand was recommended in a recent NZSEE reconnaissance team report. The use of the landslide MM criteria will benefit hazard assessments during future earthquakes in $\mathrm{NZ}$, and facilitate $M M$ reporting in areas where there are few buildings, or strong motion recorders.

(6) A preliminary earthquake-induced landslide opportunity model for New Zealand has been developed by integrating the EIL distributions and relationships with a recently developed probabilistic seismic hazard (PSH) model for New Zealand. The EIL Opportunity model provides a means of assessing the scale, character, and relative opportunity for earthquake-induced landslides in different parts of the country. The model is currently being refined and integrated with a GIS landslide susceptibility model, as one step in developing a probabilistic landslide hazard model for New Zealand.

(7) Possible future research is suggested to obtain better data of landsliding during some important historical earthquakes, and to apply the EIL relationships in palaeoseismic studies. Studies of groups of large prehistoric landslides along the central Southern Alps, northwest Nelson, and Fiordland could have important benefits for determining past and possibly future earthquake activity and hazard from active faults in those regions.

\section{ACKNOWLEDGMENTS}

The 1997 study was made possible by funding provided jointly by the Earthquake Commission and FRST-over several years, the most recent being under Contract No CO5X0006. The authors are grateful to their colleagues David Dowrick, Phil Glassey, Dick Beetham, and other GNS staff for providing data, helpful discussions, and reviews of this paper. We also wish to thank Dave Keefer (USGS) for his helpful review comments and advice. The recent contributions of Mark Stirling and Graeme McVerry in providing the PSH model used in this paper are also gratefully acknowledged.

\section{REFERENCES}

1. Abrahamson, N.A. and Somerville, P.G. (1996). Effects of hanging wall and foot wall on ground motions recorded during the Northridge earthquake. Bulletin of the Seismological Society of America 86 : 593-599.

2. Adams, J. (1980). Contemporary uplift and erosion of the Southern Alps, New Zealand. Geological Society of America Bulletin 91(II): 1-114.

3. Adams, J. (1981). Landslide-dammed lakes in New Zealand. Geology 9: 215-219.

4. Adams, R.D., Eiby, G.A., Lensen, G.J., Lowry, M.A., Stephenson, W.R., and Suggate, R.P. (1968). 
Preliminary report on the Inangahua earthquake, New Zealand, May 1968. N Z DSIR Bulletin 193.

5. Baird, H.F. (1931). The Hawkes Bay earthquake of 3 February, 1931. Unpublished Report of the, Christchurch Magnetic Observatory (now housed at the Seismological Observatory, Wellington).

6. Beetham. R., Beattie, G., Earl, B., and Duncan, D. NZ (2001). Society for Earthquake Engineering Reconnaissance Team to Seattle, USA: The February 28, 2001 Nisqually earthquake. Report of the NZSEE and MCDEM Reconnaissance Team, Bulletin of the NZ Society for Earthquake Engineering, 34(4): 253 275.

7. Berrill, J.B., Bienvenu, V.C., and Callahan, M.W. (1988). Liquefaction in the Buller Region in the 1929 and 1968 earthquakes. Bulletin of the NZ National Society for Earthquake Engineering, 21(3):174-189.

8. Berryman, K. R. (1980). Late Quaternary movement on the White Creek Fault, South Island New Zealand. New Zealand Journal of Geology and Geophysics 23:93-101.

9. Cowan, H. A. (1991). The North Canterbury earthquake of September 1, 1888. Journal of the Royal Society of New Zealand, 21(1): 1-12.

10. Crozier, M.J., Deimel, M.S., Simon, J.S. (1995). Investigation of earthquake triggering for deep-seated landslides, Taranaki, New Zealand. Quaternary International, Vol 25, pp 565-572.

11. Downes, G.L. (1995). Atlas of isoseismal maps of New Zealand earthquakes. Institute of Geological and Nuclear Sciences monograph 11, 304 p.

12. Downes, G.L., Dowrick, D.J., Van Dissen, R.J., Taber, J.J., Hancox, G.T., and Smith, E.G.C. (2001) The 1942 Wairarapa, New Zealand, earthquakes: Analysis of observational and instrumental data. Bulletin of the NZ Society for Earthquake Engineering 34: 125-157.

13. Downes, G.L., Dowrick, D., Smith, E. and Berryman, K. (1999). The 1934 Pahiatua earthquake sequence: analysis of observational and instrumental data. Bulletin of the NZ Society for Earthquake Engineering 32: 221-245.

14. Dowrick, D.J. and Smith, E.G.C. (1990). Surface wave magnitudes of some New Zealand earthquakes 1901-1988. Bulletin of the NZ National Society for Earthquake Engineering, 23(3): 198-210.

15. Dowrick, D.J. (1994). Damage and intensities in the magnitude $7.8 \quad 1929$ Murchison, New Zealand, Earthquake. Bulletin of the $\mathrm{NZ}$ National Society for Earthquake Engineering, 27(3): 190-204.

16. Dowrick, D.J. (1996). The Modified Mercalli earthquake intensity scale - revisions arising from recent studies of New Zealand earthquakes. Bulletin of the $N Z$ National Society for Earthquake Engineering, 29(2): 92-106.

17. Dowrick, D.J., and Rhoades, D.A. (1998) Magnitudes of New Zealand earthquakes, 1901-1993.
Bulletin of the $N Z$ National Society for Earthquake Engineering, 31(4): 260-280.

18. Eiby, G.A. (1966). The Modified Mercalli scale of earthquake intensity and its use in New Zealand. New Zealand Journal of Geology and Geophysics, 9:122-129.

19. Eiby, G.A. (1968). An annotated list of New Zealand earthquakes, 1460-1965. New Zealand Journal of Geology and Geophysics, 11: 630-647.

20. Fairless, G.J., and Berrill, J.B. (1984). Liquefaction during historic earthquakes in New Zealand. Bulletin of the New Zealand National Society for Earthquake Engineering, 17(4):280-291.

21. Franks, C.A.M., Beetham, R.D., Salt, G. (1989). Ground response and seismic response resulting from the 1987 Edgecumbe earthquake, New Zealand. $N Z$ Journal of Geology \& Geophysics, 32: 135-144.

22. Grapes, R.H., and Downes, G. (1997). The 1855 Wairarapa earthquake: analysis of historic data. Bulletin of the $N Z$ National Society for Earthquake Engineering 30(4): 273-368.

23. Grapes, R.H., Little, T, and Downes, G. (1997) Rupturing of the Awatere Fault during the 1848 October 16 Marlborough earthquake, New Zealand: Historical and present day evidence. New Zealand Journal of Geology and Geophysics, 1998, Vol 41: 387-399.

24 Hancox, G.T., and Perrin, N.D. (1994). Green Lake landslide: a very large ancient rock slide in Fiordland, New Zealand. Proceedings of the VII7th IAEG International Congress, Lisbon, Portugal, September 1994.

25. Hancox, G.T., Dellow, G.D., and Perrin, N.D. (1994) Wellington Regional Council: Earthquake-induced slope failure hazard study in the Wellington Region Review of historical records of earthquake-induced slope failures. Institute of Geological and Nuclear Sciences Client Report 353905.

26. Hancox, G.T., Perrin, N.D., Dellow, G.D. (1997) Earthquake-induced landsliding in New Zealand and implications for $\mathrm{MM}$ intensity and seismic hazard assessment. GNS Client Report 43601B.

27. Hansen, A., and Franks, C.A.M. (1991). Characterisation and mapping of earthquake triggered landslides for seismic zonation. State-of-the-art Paper, Proceedings of the Fourth International Conference on Seismic Zonation, Stanford, California, 1991, 1: 149-195.

28. HAZUS, 1997: Earthquake Loss Estimation Methodology-HAZUS. Report prepared by the US National Institute of Building Sciences for Federal Emergency Management Agency.

29. Henderson, J. (1937). The west Nelson earthquakes of 1929 (with notes on the geological structure of west Nelson). The $N Z$ Journal of Science and Technology, July 1937. 
30. Keefer, D.K. (1984 a). Landslides caused by earthquakes. Geological Society of America Bulletin, 95: 406-421, April 1984.

31. Keefer, D.K (1984 b). Rock avalanches caused by earthquakes: source characteristics. Science, 223(4642): 1288-1290.

32. Keefer, D.K., and Wilson, R.C. (1989). Predicting earthquake-induced landslides with emphasis on arid and semi-arid environments. Publication of the Inland Geological Society, 2: 118-149.

33. Krinitzsky, E.L. and Chang, F.K. (1988). Intensityrelated earthquake ground motions. Bulletin of the Association of Engineering Geologists, 25: 425-435.

34. Jibson, R.W., and Keefer, D.K., 1989: Statistical Analysis of Factors Affecting Landslide Distribution in the New Madrid Seismic Zone, Tennessee, and Kentucky. Engineering Geology, 27 (1989).

35. Jibson, R, W., 1996: Use of landslides for Paleoseismic analysis. Engineering Geology, 43 (1996): 291-323.

36. Kuribayashi, E., and Tatsuoka, F. (1975). Brief review of liquefaction during earthquakes in Japan. Soils and Foundations, 15(4): 81-92.

37. Lowry. A., Ede, S.S., and Harris, J.S. (1989). Assessment of seismic intensities resulting from the 1987 Edgecumbe earthquake, New Zealand, and implications for modernising the intensity scale. New Zealand Journal of Geology and Geophysics 1989, 32: $145-153$

38. McCahon, I.F., Yetton, M.D., and Cook, D.R.L. (1993). The earthquake hazard in Dunedin. Report on EQC Research Project 91/56.

39. McVerry, G.H., Zhao, J.X., Abrahamson, N.A., and Somerville, P.G. (2000). Crustal and subduction zone attenuation relationships for New Zealand earthquakes. Proceedings of the 12th World Conference on Earthquake Engineering, Auckland, New Zealand 30 January - 4 February, 2000.

40. Murchison District Historical Society and Museum Society (1999). Stories of Murchison Earthquake $17^{\text {th }}$ June 1929: Revised for $70^{\text {th }}$ Anniversary. Published and printed by Murchison District Historical Society and Museum Society Inc. June 1999.

41. Murphy, J.R., and O'Brien, J.L. (1977). The correlation of peak ground acceleration amplitude with seismic intensity and other physical parameters. Bulletin of the Seismological Society of America, 67(3): 877-915.

42. Paterson, B.R., and Bourne-Webb, P.J. (1994). Reconnaissance report on highway damage from the 18 June 1994, Arthur's Pass earthquake. Bulletin of $N \mathrm{Z}$ National Society for Earthquake Engineering, 27(3): $222-226$.

43. Paterson, B.R., Berrill, J.B. (1995). Damage to State Highway 73 from the 29 May 1995 Arthur's Pass earthquake. Bulletin of $N Z$ National Society for Earthquake Engineering, 28(4): 300-310.

44. Pearce, A.J., and O'Loughlin, C.L. (1985). Landsliding during a M 7.7 earthquake. Influence of geology and topography. Geology, 13: 855-858, December 1985.

45. Perrin, N.D. (1990). Field Inspection Report on the Dannevirke (Weber) earthquake of 13 May 1990. DSIR, $N$ Z Geological Survey Immediate Report. (Ref LD5/947, Project No. 541.400).

46. Perrin, N.D., and Hancox, G.T. (1992). Landslidedammed lakes in New Zealand: Proceedings of the Sixth International Symposium on Landslides, Christchurch, February 1992.

47. Read, S.A.L., and Cousins, W.J. (1994). The Ormond Earthquake of 10 August 1993: an overview of ground damage effects and strong-motions. in Proceedings of Technical Conference \& Annual Meeting, NZ National Society for Earthquake Engineering, Wairakei, March 1994 (p 166-175).

48. Reyners, M., McGinty, P., and Gledhill, K. (1998). Ormond New Zealand earthquake of 10 August 1993: Rupture in the mantle of the subducting Pacific plate. New Zealand Journal of Geology and Geophysics, Vol 41: 179-185.

49. Smith, W.D., and Berryman, K.R. (1986). Earthquake hazard in New Zealand: inferences from seismology and geology. Royal Society of $\mathrm{New}$ Zealand Bulletin 24: 223-243.

50. Smith, W., McVerry, G., Cousins, J., Hancox, G., Downes, G., McSaveney, M. and Rattenbury, M. (2001). GAPQuake NZ-New Zealand Earthquake Loss Modelling. Institute of Geological and Nuclear Sciences Ltd Client Report 2000/109.

51. Speight, R. (1933). The Arthur's Pass earthquake of 9th March 1929. N Z Journal of Science and Technology, 15: 173-182.

52. Stirling, M.S. (2000). New national probabilistic seismic hazard maps for New Zealand. Proceedings of the 12th World Conference on Earthquake Engineering, Auckland, New Zealand 30 January - 4 February, 2000.

53. Stirling, M.S., McVerry, G.H., and Berryman, K.R., (Submitted 2001). A new seismic hazard model for New Zealand. Manuscript submitted to the Bulletin of the Seismological Society of America, March 2001.

54. Study Group of the NZNSEE (1992). A revision of the Modified Mercalli seismic intensity scale. Bulletin of the $N Z$ National Society for Earthquake Engineering, 25(4): 345-357.

55. Suggate, R.P. (1988). Quaternary deposition and deformation in the Buller and tributary valleys. New Zealand Geological Survey Record 25: 45-51.

56. Van Dissen, R.J., Taber, J.J., Stephenson, W.R., Sritharan, S., Perrin, N.D., McVerry, G.H., Campbell, H.J., and Barker, P.R. (1992). Earthquake ground shaking hazard assessment for Wellington City and 
Suburbs, New Zealand. DSIR Geology and Geophysics Contract Report 1992/23.

57. Van Dissen, R., Cousins, J., Robinson, R., and Reyners, M. (1994). The Fiordland Earthquake of 10 August 1993: A reconnaissance report covering tectonic setting, peak ground acceleration, and landslide damage. Bulletin of the $N Z$ National Society for Earthquake Engineering, 27(3): 147-154.

58. Wilson, R. C., and Keefer, D. K., (1985). Predicting areal limits of earthquake-induced landsliding. In $\mathrm{J}$.
I. Ziony (editor): Evaluating earthquake hazards in the Los Angeles Region. US Geological Survey Professional Paper 1360: 317-493.

59. Yang, J.S. (1989). Seismotectonic study of the central Alpine Fault region, South Island, New Zealand. Unpublished PhD Thesis, Victoria University of Wellington, New Zealand. 